\title{
Strain within the ultrahigh-pressure Western Gneiss region of Norway recorded by quartz CPOs
}

\author{
NICOLAS C. BARTH ${ }^{1}$, BRADLEY R. HACKER ${ }^{1 *}$, GARETH G. E. SEWARD ${ }^{1}$, \\ EMILY O. WALSH ${ }^{2}$, DAVID YOUNG ${ }^{3} \&$ SCOTT JOHNSTON $^{4}$ \\ ${ }^{1}$ Department of Earth Science, University of California, Santa Barbara, CA 93106, USA \\ ${ }^{2}$ Department of Geology, Cornell College, Mount Vernon, IA 52314, USA \\ ${ }^{3}$ Department of Geology, University of Texas, San Antonio, TX 78249, USA \\ ${ }^{4}$ Department of Physics, California Polytechnic State University, \\ San Luis Obispo, CA 93407, USA \\ *Corresponding author (e-mail: hacker@geol.ucsb.edu)
}

\begin{abstract}
Electron back-scatter diffraction (EBSD) was used to measure the crystal preferred orientations (CPOs) from 101 samples across the ultrahigh-pressure Western Gneiss region of Norway to assess slip systems, sense of shear, CPO strength, and strain geometry. The CPOs suggest a dominance of prism $\langle a\rangle$ slip, with lesser amounts of prism [c] slip and basal $\langle a\rangle$ slip; there are few Type I and Type II girdles. The major structural feature in the study area - the high-strain, top-W, normal-sense Nordfjord-Sogn Detachment Zone - is characterized by asymmetric and strong CPOs; an eastern domain with strong asymmetric CPOs shows top-E shear. Strain throughout the study area was characterized by a mix of plane strain and constriction with no evidence of flattening. Adjacent gneiss and quartzite/vein samples have similar CPOs.
\end{abstract}

Dislocation creep can produce crystal preferred orientations (CPOs) because the difference between vorticity imposed on a crystal by deformation and the vorticity produced by dislocation glide is balanced by rotation of the crystal lattice (Taylor 1938; Lister 1982). The CPO that results is a function of factors such as the active deformation mechanisms (including dislocation slip systems), strain magnitude, rate of recrystallization, and strain geometry. As such, the CPOs of minerals, in particular, quartz, calcite, and olivine, can be used to deconvolve some of these factors and reconstruct the deformation of naturally deformed rocks.

Much emphasis has been placed on understanding and interpreting quartz CPOs because of the abundance of quartz in the continental crust. The most important slip systems in quartz are basal (0001) $\langle\mathrm{a}\rangle$ slip, prism $\{10 \overline{1} 0\}\langle\mathrm{a}\rangle$ slip, positive rhomb $\left\{\begin{array}{llll}10 & \overline{1} & 1\end{array}\right\}\langle a\rangle$ slip, negative rhomb $\left\{\begin{array}{lll}01 & \overline{1} & 1\end{array}\right\}$ $\langle\mathrm{a}\rangle$ slip, prism $\left\{\begin{array}{lll}10 & \overline{1} & 0\end{array}\right\}$ [c] slip, and Dauphiné twinning (Christie et al. 1964; Baëta \& Ashbee 1969; Blacic \& Christie 1984; Linker et al. 1984; Lloyd 2004). Activation of these slip systems is temperature dependent such that basal $\langle a\rangle$ glide at low temperatures gives way to prism $\langle a\rangle$ slip with increasing temperature, and eventually, to dominant prism [c] slip (Blacic 1975; Blumenfeld et al. 1986). Assuming that the slip plane rotates toward the shear plane and that the slip direction rotates toward the shear direction of an imposed deformation, the activity of that slip system can be inferred from a CPO. This assumption is unjustified in general, however, because crystals are constrained by neighbouring grains and multiple slip-systems are typically active simultaneously (Lister et al. 1978; Lister \& Hobbs 1980; Wenk et al. 1989; Wenk \& Christie 1991; Casey \& McGrew 1999). Instead, CPOs reflect variations in the rates of lattice rotation, with slow rates of rotation forming maxima (Wenk \& Christie 1991).

Progressive strain of a polycrystal leads to progressive rotation of the crystal lattices and, therefore, to a relationship between strain magnitude and CPO strength (Lister et al. 1978); this relationship has been demonstrated in both experimentally and naturally deformed rocks (Marjoribanks 1976; Bouchez 1977; Carreras et al. 1977; Miller \& Christie 1981; Law 1986; Dell'Angelo \& Tullis 1989; Heilbronner \& Tullis 2006). Other factors that influence CPO strength include the particular slip systems that are active, the activity of other deformation mechanisms, the rate of recrystallization, the presence of other phases and variations in strain path (e.g. Knipe \& Law 1987; Casey \& McGrew 1999). Also, CPO strength is expected to reach a steady state, beyond which further strain will not be recorded (Wenk \& Christie 1991).

Quartz CPOs in experimentally deformed rocks (Tullis et al. 1973), naturally deformed rocks 
(Bouchez et al. 1983) and simulated rocks (Lister et al. 1978; Wenk et al. 1989) can reflect whether the imposed strain was coaxial or non-coaxial. This relationship has been exploited to infer the sense of shear in naturally deformed rocks, by using the sense of asymmetry between the flow plane inferred from the $\mathrm{CPO}$ skeleton and the flattening plane defined by the foliation (Behrmann \& Platt 1982). This techniques is expected to be inaccurate, to some degree, because the relationship between the $\mathrm{CPO}$ skeleton and the kinematic framework is likely to be more complex than assumed (Wenk \& Christie 1991).

Quartz CPOs in experimentally (Dell' Angelo \& Tullis 1989; Heilbronner \& Tullis 2006) and naturally (Price 1985; Law 1986) deformed rocks have been shown to depend on strain geometry or distortion; simulations have also shown a dependence of CPOs on strain geometry (Lister et al. 1978; Bascou et al. 2002). In favourable circumstances the reverse relationship - using quartz CPOs to determine strain geometry or distortion - can be exploited (Schmid \& Casey 1986). If one makes the simplifying assumption that principal slip planes rotate until they are parallel to the shear plane and slip directions rotate parallel to the shear direction, a CPO that results from plane strain should have the form of a single crystal if only one slip system is active (Fig. 1). During pure flattening, slip planes rotate away from the shortening direction and the absence of a unique extension direction means that the slip directions are dispersed evenly; thus, the slip directions define a girdle if only one slip system is active (Fig. 1). Conversely, during pure constriction, the slip directions become aligned and the absence of a unique flattening plane means that the slip planes are dispersed evenly; thus, the poles to the slip planes define a girdle if only one slip system is active (Fig. 1). Actual CPOs are, of course, more complex for the reasons outlined above.

\section{Purpose and analytical methods}

The main purpose of this study is to semiquantitatively assess strain geometry (i.e. the degree to which the strain deviated from plane strain toward flattening or constriction) using a large quartz CPO dataset. The same data are also used to assess active slip systems, CPO strength and sense of shear. The samples are mostly quartzofeldspathic gneisses, quartzites, and quartz veins from the Western Gneiss region of Norway deformed at chiefly amphibolite-facies conditions. The CPO data were collected from $\mathrm{X}-\mathrm{Z}$ thin sections (i.e. perpendicular to foliation and parallel to lineation) by electron back-scatter diffraction (EBSD) using a JEOL JSM-6300V digital SEM coupled with a HKL Nordlys EBSD camera and Channel 5 software. To create a $\mathrm{CPO}$, the processed data were reduced to one point per grain, using a $15^{\circ}$ misorientation to define grain boundaries. Pole figures of quartz [c] and $\langle\mathrm{a}\rangle$ axes were created and contoured using the PFch5 software (Mainprice 2005).

The modal proportions of quartz, feldspar, and 'other' phases were determined from the area proportions of phases indexed during the EBSD measurements. These values were rounded to the nearest $5 \%$ to indicate their probable accuracy at the thin-section scale.

The orientations of the CPO eigenvectors (Ulrich \& Mainprice 2005) define the orientation of the CPO skeleton. The asymmetry of the CPO skeleton with respect to the rock foliation and lineation was used to determine sense of shear (Behrmann \& Platt 1982). The validity of this method hinges on the assumptions that: i) the preferred glide plane is sufficiently close to the shear plane that the apparent sense of shear is not reversed; and ii) the strain that produced the $\mathrm{CPO}$ and the strain that produced the foliation were not sufficiently different to give the wrong sense of shear.

To assess CPO strength we use the $J$ index (Bunge 1982) for the $c$-axes and $a$-axis fabrics. To determine strain geometry, we use the basic precepts implied by Lister et al. (1978) and expanded upon by Price (1985) (Fig. 1), inferring that the CPO skeleton reflects the strain geometry and the active slip systems. For example, deformation solely by prism $\langle a\rangle$ slip is expected to produce a $c$-axis maximum during simple shear plane strain, a $c$-axis girdle in the $\mathrm{X}-\mathrm{Y}$ plane during flattening, and a $c$-axis girdle in the $\mathrm{Y}-\mathrm{Z}$ plane during constriction. In this view, the extent that a given $c$-axis distribution falls between a maximum and a girdle can be used to determine the extent to which the strain was a mixture of plane strain and constriction. This determination can never be more than semiquantitative, for many reasons alluded to above, not the least of which are that slip systems and strains vary from grain to grain in rocks. Of particular relevance to amphibolite-facies deformation of quartz is that $\langle a\rangle$ pencil glide can occur along a combination of basal, prism and rhomb planes; if these slip systems are active in concert, even plane strain may yield a CPO in a naturally deformed rock that is indistinguishable from the CPO expected for constriction-imposed slip on the basal 〈a system or prism 〈a system alone (Fig. 1) (Schmid \& Casey 1986).

For a semi-quantitative measure of the degree to which a CPO defines a maximum or a girdle, we use $P f c h 5$ (Mainprice 2005) to calculate the $P, G$ and $R$ indices of the $c$-axis distribution (Woodcock 1977; Vollmer 1990; Ulrich \& Mainprice 2005). The magnitudes of the indices reflect how well the data define a point $(P)$, girdle $(G)$ or random $(R)$ 


\section{basal < a > slip}

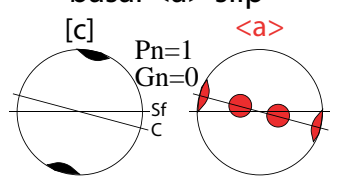

simple shear

Pure shear

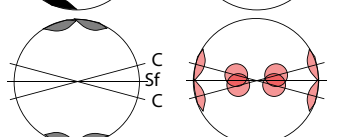

Dextral

non-coaxial + flattening

Coaxial flattening

Dextral non-coaxial + constriction

Coaxial constriction basal $<a>+$ prism $<a>$

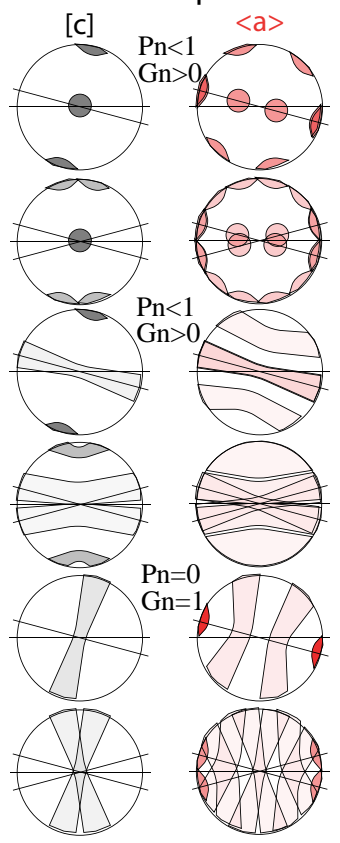

prism <a > slip

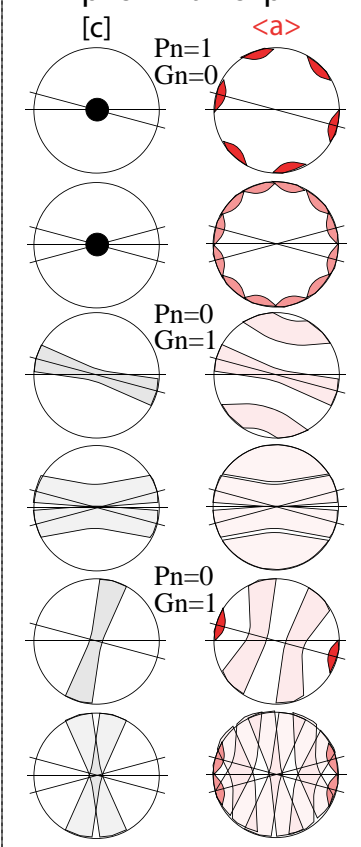

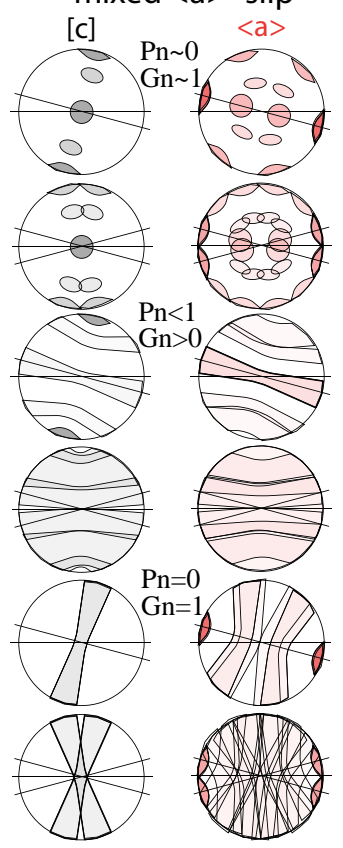
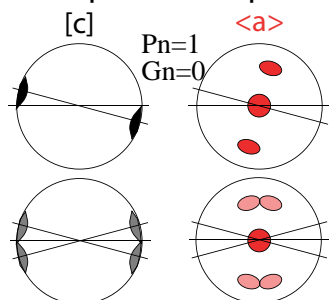

$\mathrm{Pn}=0$
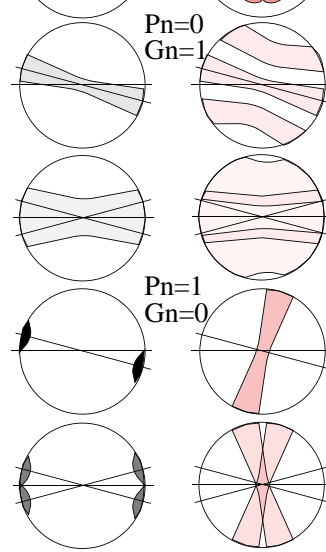

Fig. 1. CPOs and normalized point $\left(P_{n}\right)$ and girdle $\left(G_{n}\right)$ indices expected from various quartz slip systems subjected to different strain geometries. In each stereonet, foliation (Sf) is horizontal, shear/cisaillement (C) planes are inclined, and lineation is at the intersection of the foliation with the primitive (i.e. east-west). 
distribution. The $R$ value serves as a measure of CPO strength, with $R=1$ indicating the absence of a preferred orientation. These values can be displayed in a triangular 'Vollmer' diagram (Abalos 1997) that has apices of $P, G$ and $R$. To remove the $R$ component from the determination of the strain geometry, we calculate normalized point $\left(P_{n}\right)$ and girdle $\left(G_{n}\right)$ values:

$$
\begin{aligned}
P_{n} & =P /(P+G) \\
G_{n} & =G /(P+G)
\end{aligned}
$$

or

$$
G_{n}=1-P_{n}
$$

In the case of basal $\langle\mathrm{a}\rangle$ slip, a low $P_{n}$ value indicates constriction (Fig. 1). A high $P_{n}$-value is compatible with plane strain or flattening; the distinction between the two possibilities must be made on the basis to which the $\langle a\rangle$ axes define point maxima or a girdle. In the case of prism $\langle\mathrm{a}\rangle$ slip, a high $P_{n}$-value indicates plane strain. A low $P_{n}$-value is compatible with constriction or flattening; the distinction between the two possibilities can be made by using the orientation of the [c] girdle with respect to the foliation: a girdle in the $\mathrm{Y}-\mathrm{Z}$ plane indicates constriction and a girdle in the $\mathrm{X}-\mathrm{Y}$ plane indicates flattening. In the case of prism [c] slip, a low $P_{n}$-value indicates flattening. A high $P_{n}$ value is compatible with constriction or plane strain; the distinction between the two possibilities must be made on the extent to which the $a$-axes define point maxima or a girdle. In the case of 'mixed $\langle a\rangle$ ' slip (slip in the $\langle\mathrm{a}\rangle$ direction along all planes, or pencil glide), the resulting CPOs cannot easily be deconstructed using $P_{n}$ because the $c$-axes effectively form one or more girdles regardless of whether the strain is plane or constrictional; flattening achieved by $\langle a\rangle$ slip along multiple planes will lead to an increased $R$ component. Thus, only the $P_{n}$ values for 'prism $\langle\mathrm{a}\rangle$ ' CPOs are definitive of constriction v. plane strain and only when the orientation of the $c$-axis girdle is considered. $P_{n}$ values for 'basal $\langle\mathrm{a}\rangle$ ' CPOs cannot distinguish between plane strain and flattening and $P_{n}$ for 'prism [c]' CPOs cannot differentiate constriction from plane strain. Simple $P_{n}$ values for 'mixed $\langle$ a' slip are not useful for assessing strain geometry.

\section{The Western Gneiss region ultrahigh-pressure terrane}

The formation and exhumation of ultrahighpressure (UHP) rocks are important aspects of collisional orogenesis and are intrinsic to a number of Earth processes, including the generation and collapse of mountain belts, crust-mantle material exchange and the chemical refining of continental crust (Hacker 2007). The Western Gneiss Region (WGR) of Norway (Fig. 2), the root zone of the Scandinavian Caledonides, is the best-exposed giant UHP terrane on Earth and is thus a prime locale to study UHP processes. The bulk of the WGR consists of quartzofeldspathic Baltica basement gneiss overlain by minor crystalline and metasedimentary allochthons. High-pressure (HP) rocks cover $60000 \mathrm{~km}^{2}$, and UHP rocks, defined by the presence or absence of coesite, crop out in three antiformal domains along the coast (Hacker 2007). Peak metamorphic temperatures increase from $c .600{ }^{\circ} \mathrm{C}$ in the $\mathrm{SE}$ to $800^{\circ} \mathrm{C}$ in the $\mathrm{NW}$ (Fig. 2) (Griffin et al. 1985; Kylander-Clark et al. 2008). Subduction of the WGR was underway by $420 \mathrm{Ma}$ and exhumation to mid-crustal levels was complete by $400-$ $380 \mathrm{Ma}$ (Kylander-Clark et al. 2007; Walsh et al. 2007).

Aspects of the exhumation history of the WGR that are not well understood include the spatial and temporal variations in: i) the sense of shear; ii) the magnitude of strain; and iii) the geometry of strain. The bulk of the exhumation-related fabrics are associated with east-west amphibolitefacies stretching, although older fabrics (including granulite and eclogite facies) are locally preserved (Terry \& Robinson 2003, 2004). The principal structure responsible for exhumation of the WGR through crustal depths is the Nordfjord-Sogn Detachment Zone (Fig. 2) (Johnston et al. 2007a). This zone is characterized by amphibolite- to greenschist-facies asymmetric structures that indicate top-to-the-west, normal-sense shear within the allochthons; it is well developed within the lower few $\mathrm{km}$ of the allochthons, but fades rapidly into the underlying crystalline basement (Andersen et al. 1994; Labrousse et al. 2002; Hacker et al. 2003; Young 2005; Johnston et al. 2007a). A topto-the-east, amphibolite-facies high-strain zone occurs along the eastern edge of the crystalline basement.

Assessing the strain geometry of the WGR is important for understanding how the WGR was exhumed. Andersen et al. (1991) suggested that the WGR might contain constrictional fabrics formed as the buoyant continental crust tore loose from its sinking lithospheric root; Terry \& Robinson (2003, 2004) described eclogite- and amphibolitefacies structures compatible with this. Andersen \& Jamtveit (1990) reported symmetrical structures indicating eclogite- and amphibolite-facies coaxial deformation. Krabbendam \& Wain (1997) observed $\mathrm{L}$ fabrics in augen gneiss and lineation-parallel folds in layered gneiss and concluded that the WGR experienced constrictional east-west extension, north-south shortening and vertical thinning during amphibolite-facies metamorphism. Walsh \& Hacker (2004) noted that if the ascent of the WGR was 


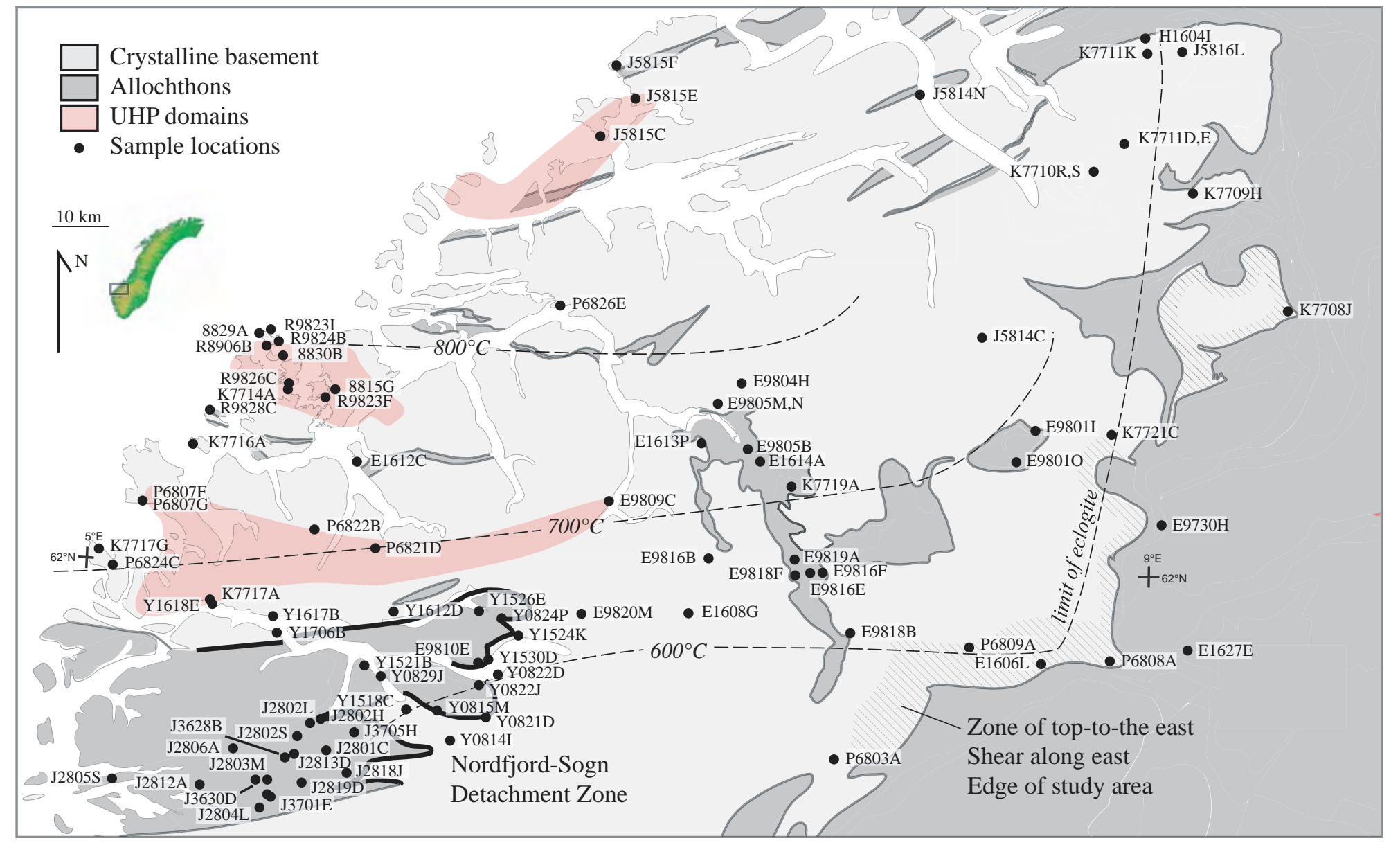

Fig. 2. The Western Gneiss region of Norway consists of a crystalline basement overlain by allochthons emplaced toward the SE. Major features include the ultrahigh-pressure (UHP) domains, the top-to-the-west Nordfjord-Sogn Detachment Zone and the top-to-the-east shear zone along the eastern edge of the crystalline basement. Peak metamorphic temperatures increase toward the NW (Kylander-Clark et al. 2008); the CPOs reported here reflect either these or lower temperatures. 
arrested at the Moho because of neutral buoyancy it might have undergone large-scale flattening.

\section{Data}

This study included 101 quartz-bearing rock samples from the WGR: 64 samples newly analysed and 37 from previous studies (Fig. 2, Appendix 1). Because previous studies generally focused on small areas, this study made an effort to broaden the spatial distribution of the samples; the result (Fig. 2), however, is still quite uneven and this should be borne in mind when interpreting the dataset. The rocks are chiefly quartzofeldspathic gneisses, quartzites, and veins, with a few anorthosites, granulites and eclogites. Minerals present in the gneisses include quartz, plagioclase, K-feldspar, garnet, biotite, muscovite, chlorite, hornblende, orthopyroxene, epidote, zoisite, sphene and kyanite. Most samples contain simply quartz \pm feldspar \pm mica. At some localities, suites of different rock types (quartzite v. anorthosite v. gneiss or eclogite v. quartzofeldspathic gneiss) were measured to assess the effect of rock type on the CPO recorded. At other localities, veins were measured separately from the host rocks for the same reason.

\section{Optical microstructures of samples}

Optically visible sample microstructures are summarized in Appendix 1 and Figure 3. The bulk of the samples display microstructures typical of regime 3 deformation/recrystallization conditions dentate grain boundaries, a modest range of grain sizes, island grains and an absence of core-andmantle microstructures - implying a mix of subgrain-rotation and grain-boundary migration recrystallization (Hirth \& Tullis 1992; Stipp et al. 2002). Fewer samples show characteristics of regime 2: ribbon grains, core-and-mantle microstructures and deformation lamellae (Fig. 3). The amount of quartz in some samples is so low, 20-30\%, that the grains were likely pinned by their neighbours and did not undergo pure dislocation creep.

\section{Active slip systems}

Most samples show strong lattice preferred orientations with multiples of uniform distribution (m.u.d.) of three or more; a few have m.u.d. $>20$ (Fig. 4). About half of the samples have CPOs with a $c$-axis maximum subparallel to the $\mathrm{Y}$ strain direction, compatible with prism $\langle\mathrm{a}\rangle$ slip. About two dozen samples have CPOs with a $c$-axis girdle sub-perpendicular to the $\mathrm{X}$ strain direction, evocative of $\langle a\rangle$ slip on multiple planes (i.e. pencil glide). Both of these types of CPO are distributed evenly across the study area (Fig. 5). Another eight samples have CPOs with a $c$-axis maxima subparallel to X, implying prism [c] slip. These samples are all from a relatively small area around the UHP domains in the western part of the study area; some of them are eclogites, others are veins associated with eclogites, and others are nearby gneisses. The two granulite-facies samples have obscure CPOs. About ten samples have CPOs with a $c$-axis maximum sub-parallel to $Z$, suggesting basal $\langle a\rangle$ slip; these samples are widely scattered, but form a small cluster in the centre of the study area (Fig. 5). The bulk of the samples thus experienced slip on systems typical of amphibolite-facies deformation; the few basal 〈a〉 slip and prism [c] slip CPOs imply greenschist-facies and granulite- or eclogite-facies deformation, respectively.

\section{Age of the CPOs and microstructures}

Several lines of evidence indicate that the bulk of the quartz CPOs and microstructures reported in this study formed during the amphibolite-facies exhumation of the WGR that postdated the UHP event.

1. In the WGR, the amphibolite-facies structures overprint local eclogite-facies structures (typically forming fractures, strain shadows, and shear zones), indicating that they are younger.

2. Quartz grains within the three UHP domains are presumed to be pseudomorphs after coesite and therefore may have had a random orientation upon formation (Hacker \& Peacock 1995; Lenze \& Stöckhert 2007).

3. Several samples (particularly quartz veins P6824C2, K7711E2 and E9820M9) have strong CPOs that are not coaxial with respect to the rock foliation, suggesting that the quartz microstructure is younger than the foliation.

4. Most samples exhibit undulatory extinction; if that undulatory extinction had developed during an earlier deformation it would have been annealed during a static amphibolitefacies event. Samples containing CPOs formed under granulite- and eclogite-facies are exceptions to this general rule; however, as these fabrics are relics of an earlier deformation that predates this static amphibolite facies event that was associated with exhumation.

\section{Sense of shear}

Sixty-four of the $c$-and $a$-axis CPOs are asymmetric with respect to the rock foliation; 21 are symmetrical and 16 are indeterminate. The asymmetric CPOs, implying noncoaxial deformation, and the symmetric CPOs, implying coaxial deformation, show spatial distributions (Fig. 5). The CPOs of samples around the Nordfjord-Sogn Detachment Zone in the west are almost uniformly indicative 

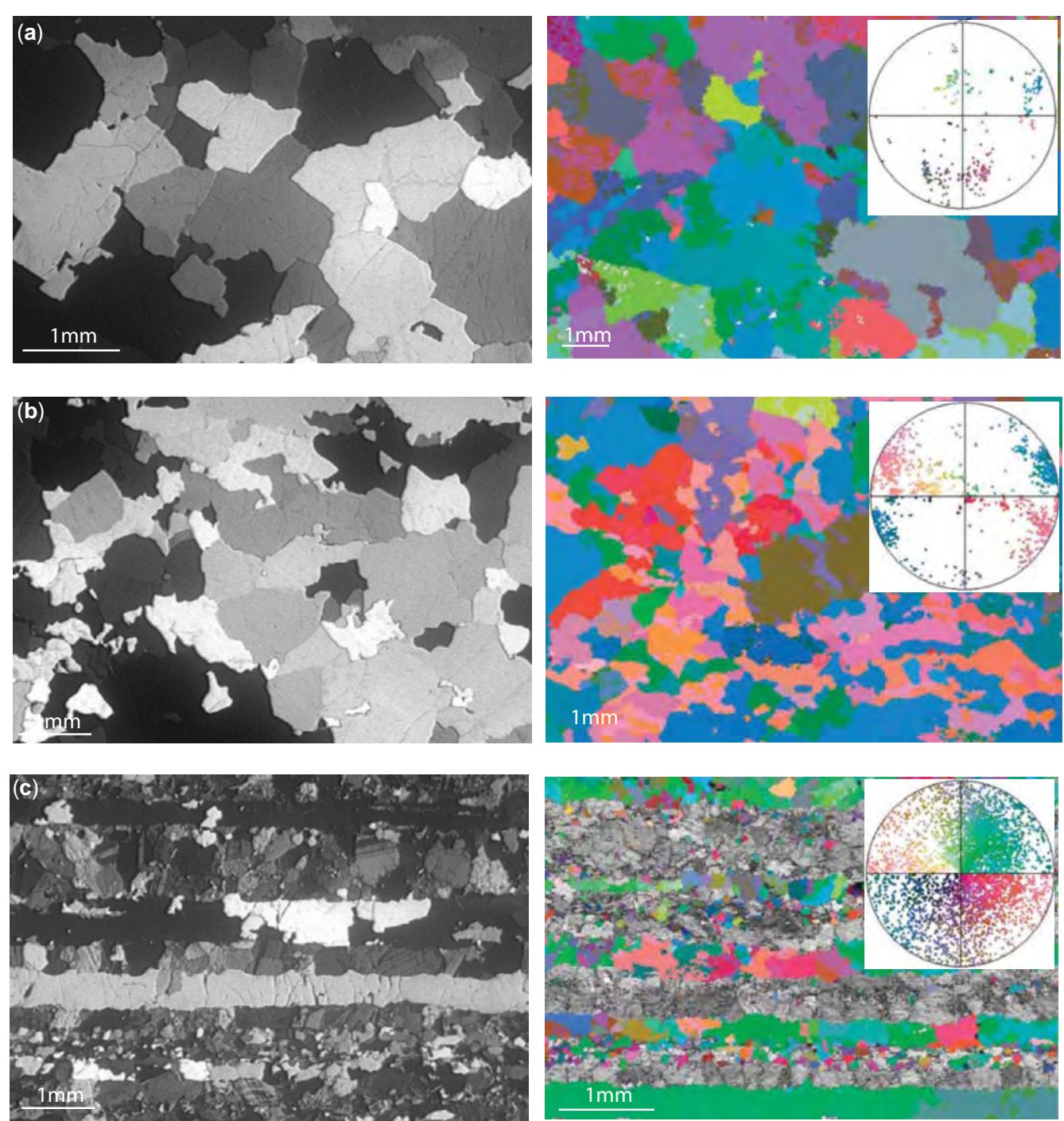

Fig. 3. Representative microstructures. Optical microstructures (left) are indicative of quartz deformation regime 2 (a few samples) or 3 (most samples); cross-polarized light. EBSD map coloured by one-point-per-grain quartz crystal orientations shown in inset $c$-axis stereonet. (a) Quartz vein P6807F7 showing weak undulatory extinction, weak sub-grain formation, and fairly straight grain boundaries indicative of quartz deformation regime 3. (b) Quartz vein in eclogite K7717A2 showing weak undulatory extinction, modest sub-grain formation, and straight grain boundaries indicative of regime 3. (c) Gneiss sample R9823F9 composed of bands of quartz and plagioclase.

of top-to-the-west amphibolite-facies shearing (Young 2005; Johnston et al. 2007b). The central part of the study area is characterized by a mix of symmetric CPOs that imply coaxial sample-scale deformation, and sub-equal numbers of asymmetric CPOs that imply top-to-the-west and top-to-theeast sample-scale shearing. Together, these CPOs imply that the central domain underwent broadly coaxial deformation. The inferred slip systems of these samples are compatible with amphibolite-facies deformation. The central domain and the Nordfjord-Sogn Detachment Zone are separated by a transitional domain characterized by a mixture of CPOs suggesting top-tothe-west and coaxial shearing from amphibolite facies down to greenschist facies. Within this domain is a smaller domain of CPOs compatible with a mix of top-to-the-west and top-to-the-east shearing during eclogite-or granulite-facies deformation. Along the eastern edge of the WGR is a 

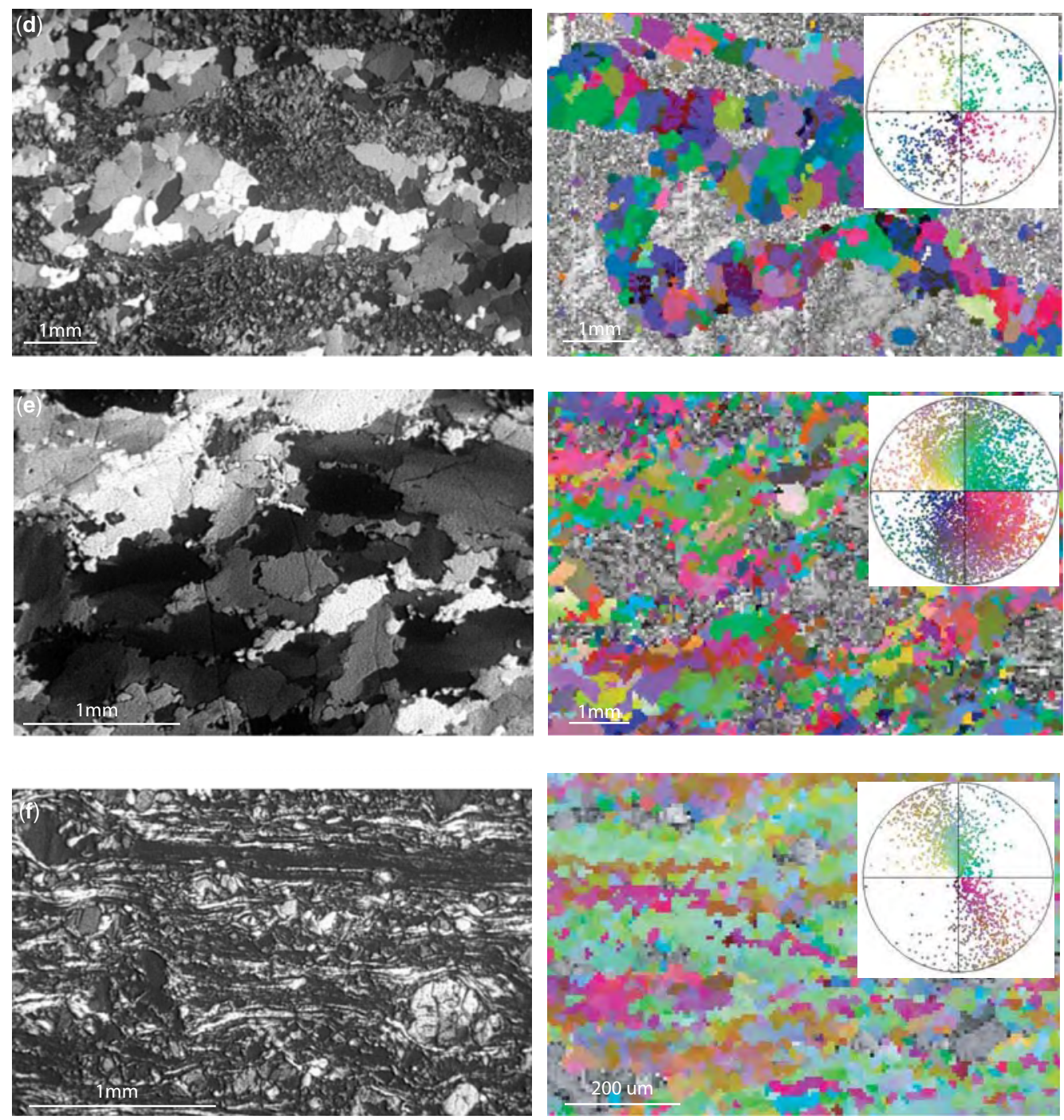

Fig. 3. (Continued). Regime 3. (d) Gneiss sample P6821D1 with quartz-rich zones surrounded by fine-grained symplectites. Grain boundaries are dentate. Regime 3. (e) Gneiss sample P6803A2 with strong undulatory extinction, strong sub-grain formation, and dentate grain boundaries indicative of sub-grain rotation recrystallization (regime 2). (f) Quartz-rich ultramylonite J3701E3 with highly stretched quartz grains and feldspar porphyroclasts. Regime 2.

fourth domain with CPOs implying top-to-the-east shearing, again compatible with field observations.

\section{CPO strength}

The CPO strength, as determined by $J_{[\mathrm{c}]}, J_{\langle a\rangle}$ or $1-R$, shows modest spatial variation (Fig. 6). Samples around the high-strain Nordfjord-Sogn Detachment Zone and from an area in the eastern part of the study area have strong CPOs, whereas samples everywhere else have weaker CPOs.

\section{Strain geometry}

The distributions of the $P G R$ data for the different CPOs (Fig. 4) imply that the strain that produced the CPOs was a mix of plane strain and constriction, with minimal flattening. Most of the CPOs that are compatible with basal $\langle a\rangle$ slip have relatively high $R$-values that render their interpretation suspect. Of the five samples with low $R$-values, one, $\mathrm{J} 2803 \mathrm{M}$, has a $c$-axis girdle that might indicate constriction. The remaining low- $R$ samples have 


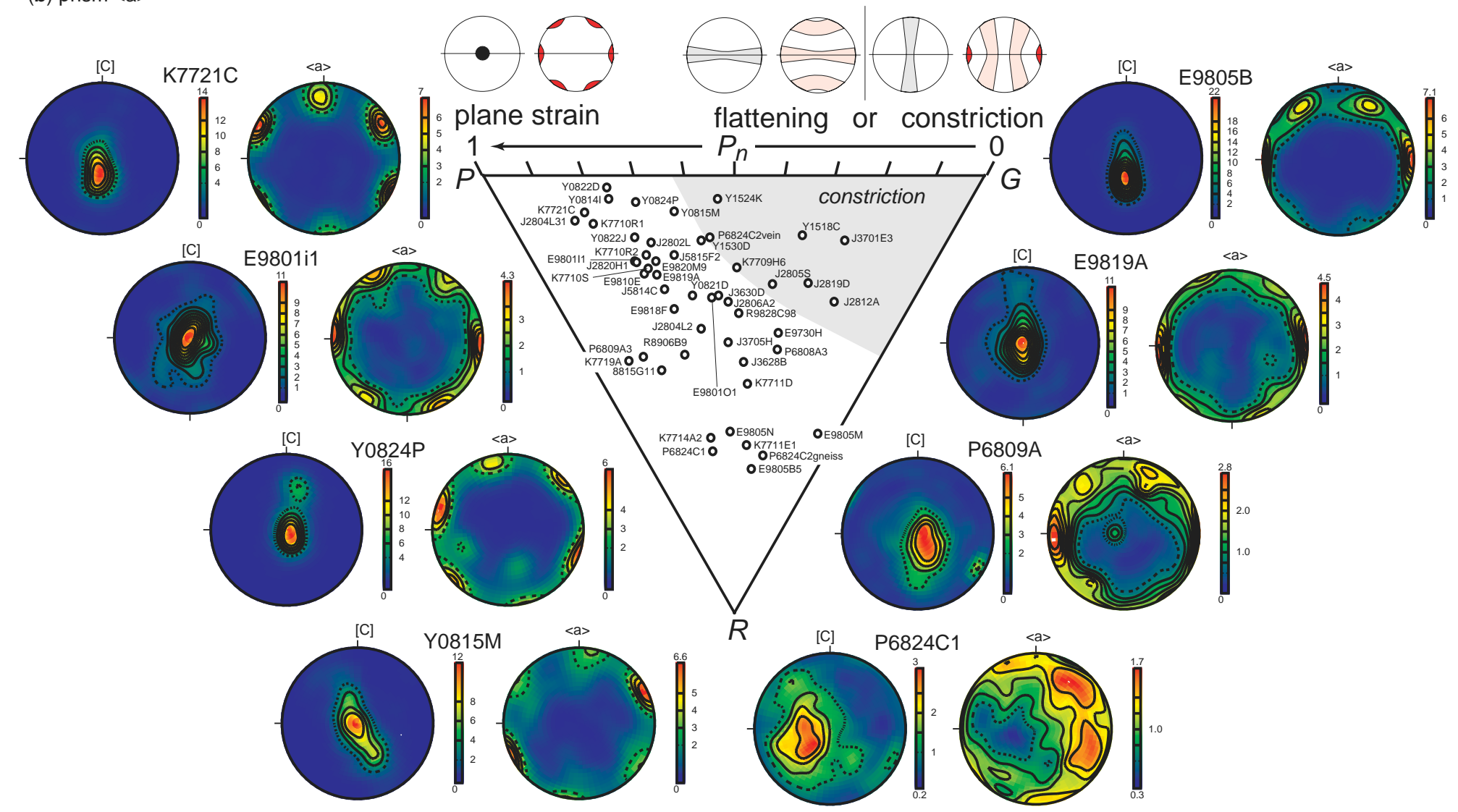

Fig. 4. (Continued) (b) CPOs attributable to prism $\langle$ a $\rangle$ glide have characteristics compatible with a mix of plane strain and constriction, with the former dominant; none are compatible with flattening. 
(d) prism [c]
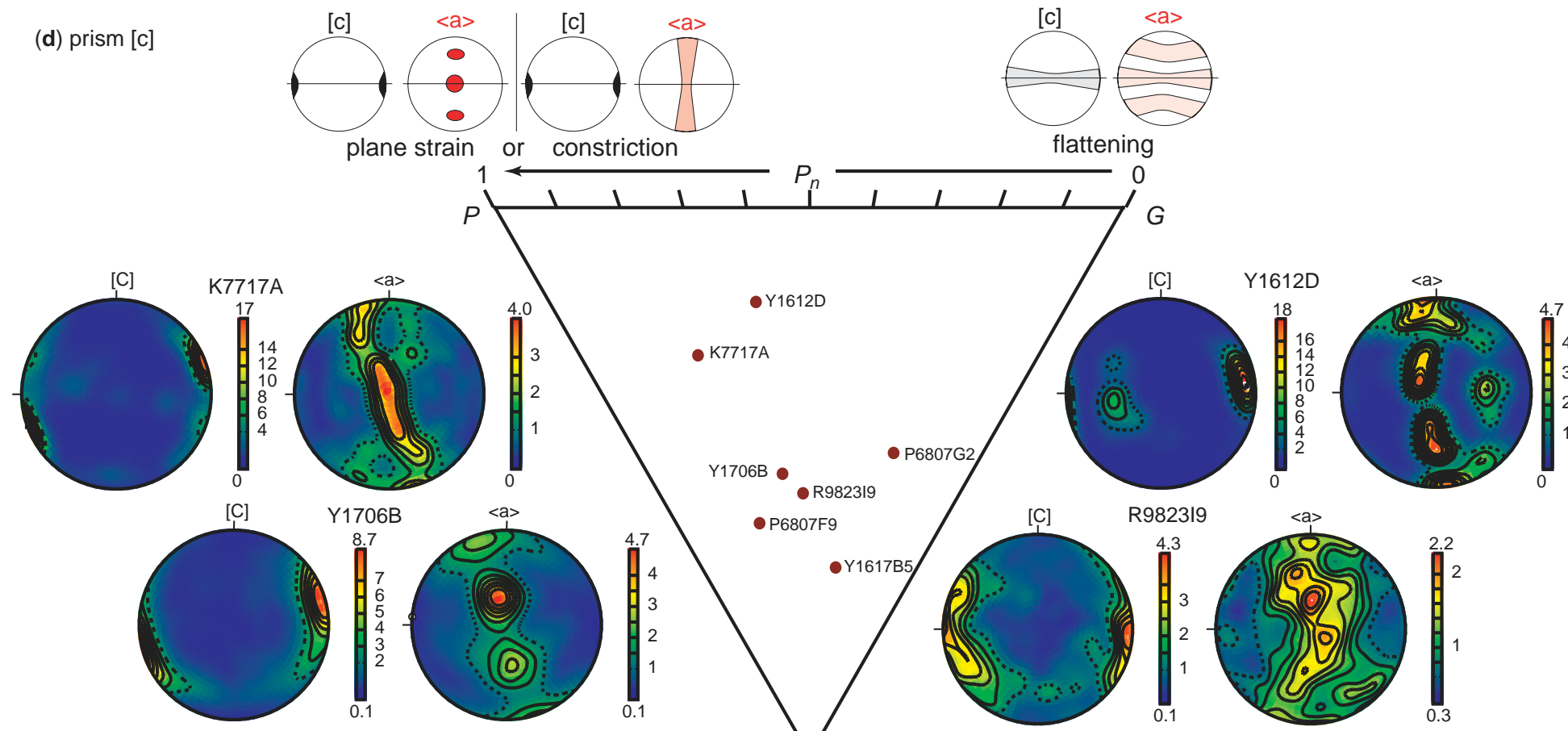

- P6807F9

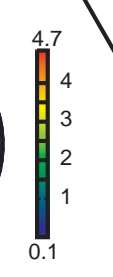

R982319
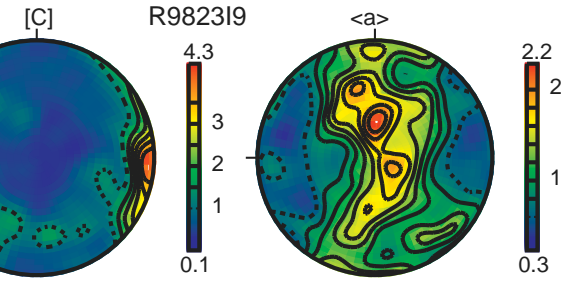

Fig. 4. (Continued) (d) CPOs attributable to prism [c] slip are compatible with either plane strain (e.g. Y1706B) or constriction (e.g. K7717A). 


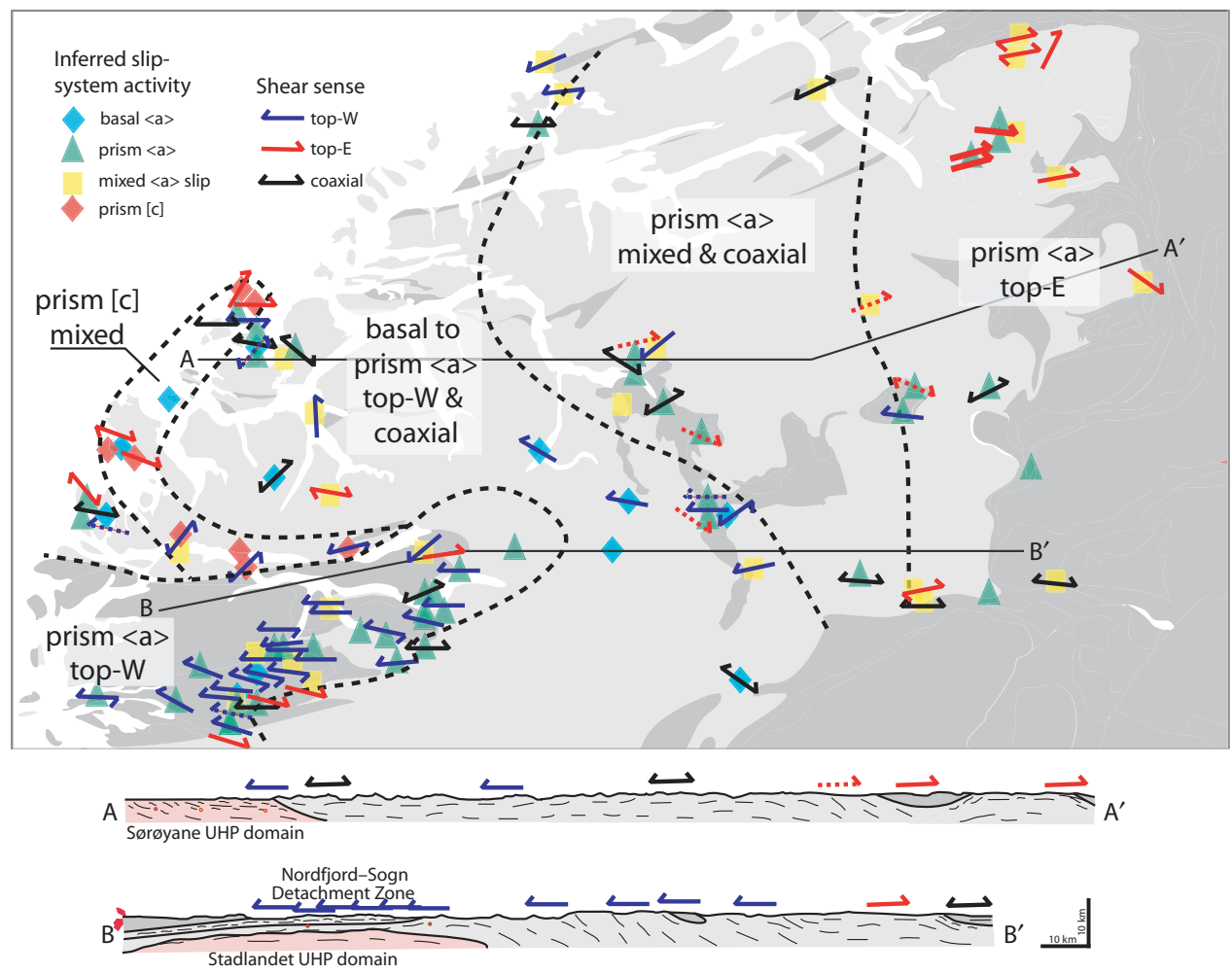

Fig. 5. Slip systems and shear sense inferred from CPOs show distinct domains: top-to-the-west prism $\langle a\rangle$ slip along the Nordfjord-Sogn Detachment Zone, mixed prism [c] slip in the west near the southernmost UHP domain, and a transition to top-to-the-east shear farther east. Dashed arrows indicate less robust data.

CPOs compatible with plane strain (e.g. P6822B1) or flattening (e.g. J2813D). The CPOs that are compatible with prism $\langle a\rangle$ slip indicate a mix of plane strain and constriction, with the former dominant; none are suggestive of flattening. The CPOs that are compatible with 'mixed $\langle\mathrm{a}\rangle$ ' slip are, de facto, all compatible with constriction and plane strain, but, as noted above, $P_{n}$ cannot distinguish between those two possibilities. The CPOs that are compatible with prism [c] slip samples are suggestive of either plane strain (e.g. Y1706B) or constriction (e.g. K7717A).

Figure 7 shows the spatial distribution of the $P_{n}$ data for the 'prism $\langle\mathrm{a}\rangle$ ' slip samples; samples with high $R$ values or obscure CPOs were excluded (see Appendix 1). Adding the 'basal $\langle\mathrm{a}\rangle$ ' slip and $1-P_{n}$ for the 'prism [c]' samples does not affect the general pattern. The greatest constrictional component (low $P_{n}$ values) is recorded in the centre of the study area (Fig. 7).

\section{Rock-type comparisons}

At six locations, different types of rock were measured to assess how the presence of minerals other than quartz affected the CPOs. A quartzite and a gneiss sample at E1606L record CPOs that look similar despite the percentage of quartz varying by a factor of two (Appendix 1). A quartzite and a vein sample at K7710R have almost identical amounts of quartz and recorded essentially identical CPOs. Three K7711E samples, a gneiss, a quartzite and a vein, have partial to complete $c$-axis girdles subperpendicular to $\mathrm{X}$; the $\mathrm{CPO}$ in the quartzite (K7711E3) is the most straightforward, and the $\mathrm{CPO}$ in the gneiss (K7711E1 is the most obscure. The three eclogite-facies samples from P6807F have obscure, but similar, CPOs. The two gneiss samples from P6824C have similar CPOs suggesting prism $\langle a\rangle$ or mixed $\langle a\rangle$ slip, whereas the vein sample (P6824C2) has a clearly defined prism $\langle$ a $\rangle$ CPO.

\section{Discussion}

\section{Implications for deformation of the Western Gneiss Region}

The quartz CPO data presented above provide useful information regarding the exhumation 


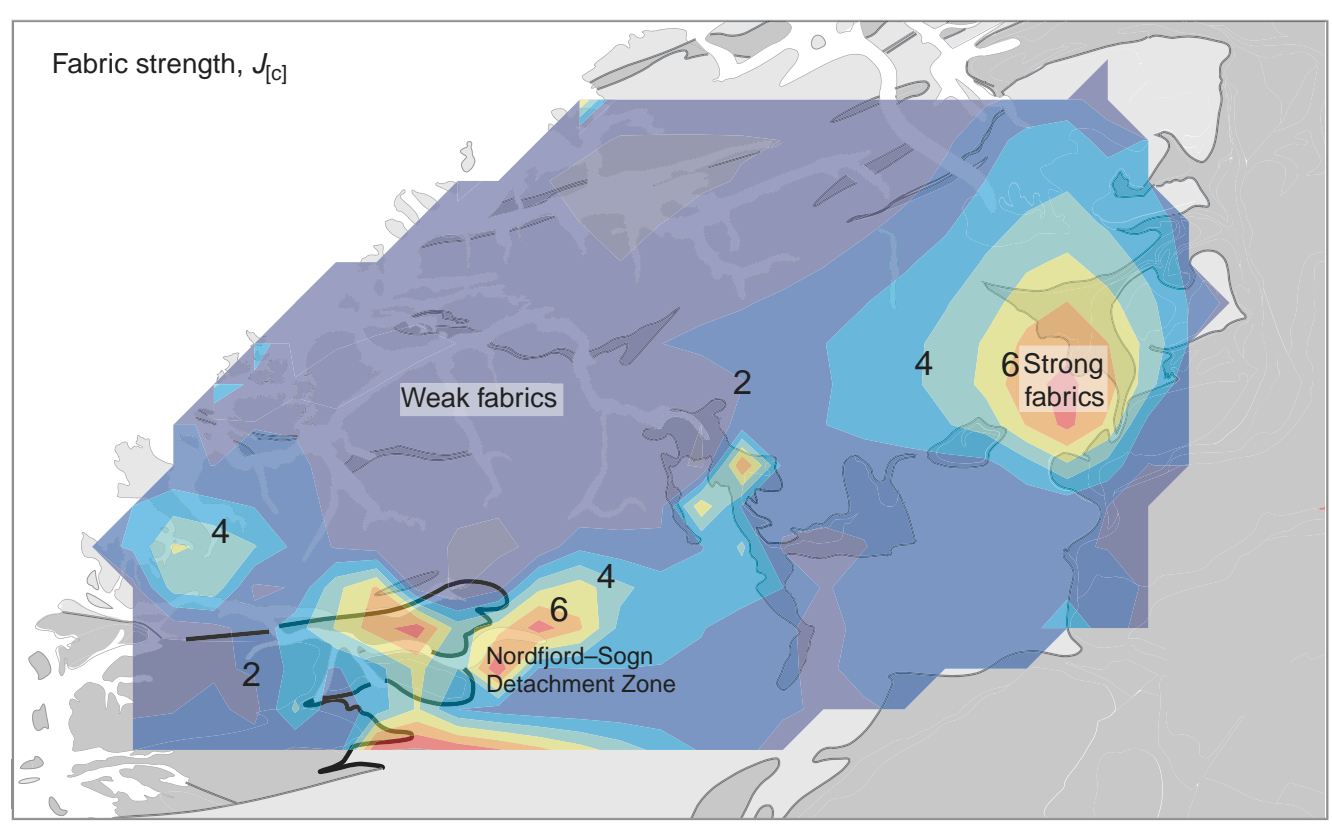

Fig. 6. As measured by $J_{[\mathrm{c}]}$ value ( $J_{\langle\mathrm{a}\rangle}$ is nearly identical and $1-R$ is similar), CPOs are strongest along the NordfjordSogn Detachment Zone and within the top-to-the-east domain in the east. Contoured using the Matlab griddata(cubic) routine.

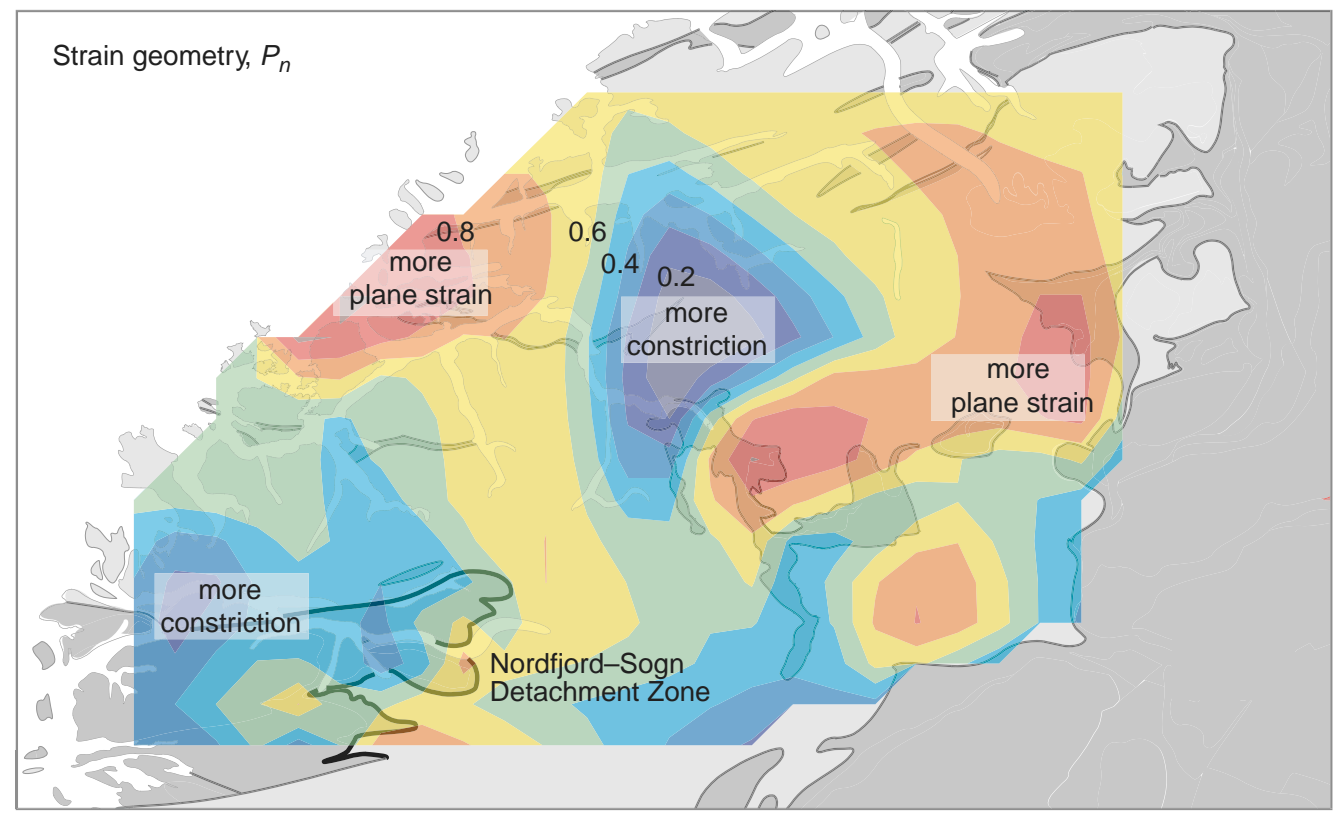

Fig. 7. The constrictional component inferred from CPOs using $P_{n}$ is weakest in the south(east) and strongest in the north(west). Only samples with $P_{n}$ values listed in Appendix 1 were used (i.e. samples with large $R$ values or obscure CPOs were excluded). Contoured using the Matlab griddata(cubic) routine. 
of the WGR. Although most of the CPOs imply amphibolite-facies mixed $\langle\mathrm{a}\rangle$ slip and prism $\langle\mathrm{a}\rangle$ slip, the presence of CPOs in a minority of samples suggesting prism [c] slip indicates that vestiges of hotter deformation remain. The sense-of-shear interpretations imply that the hottest deformation (recorded by prism [c] CPOs) was coaxial at a large scale (a mixture of top-tothe-west and top-to-the-east), compatible with the interpretation of field structures by Andersen \& Jamtveit (1990). The rest of the sense-of-shear interpretations show a clear east-west transition: an eastern domain with top-to-the-east amphibolitefacies deformation, a central coaxial domain that is mostly amphibolite-facies, but locally greenschist facies, and strong top-to-the-west, normal-sense shearing along the Nordfjord-Sogn Detachment Zone. The extent to which the top-to-the-west deformation within the Nordfjord-Sogn Detachment Zone extends downward to deeper structural levels within the crystalline basement - as shown by the new CPOs - was not previously recognized. The eastern domain of top-to-the-east shearing is associated with emplacement of the allochthons over the basement; that this deformation is chiefly amphibolite-facies was not previously known.

As noted above, numerous factors influence CPO strength, including the particular slip systems that are active, the activity of other deformation mechanisms, the rate of recrystallization, the presence of other phases, and variations in strain path, including strain magnitude. Two domains in the study area, the Nordfjord-Sogn Detachment Zone and the eastern margin of the crystalline basement, have outcrop features - reduced grain size, stronger foliations, and strong fabric asymmetry indicating high strain magnitude. These two domains do indeed have strong CPOs locally (as measured by $J_{[\mathrm{c}]}$ of quartz), implying that dislocation creep of quartz was a significant deformation mechanism.

The strain geometries calculated in this study from quartz CPOs are a mix of plane strain and constriction, with minimal evidence of a flattening component. Because of the relatively low strains necessary to reset quartz CPOs, these are true constrictional strains and not 'apparent' constriction that might result from, for example, the superposition of orthogonal flattening strains. The evidence of widespread true constriction is consistent with the suggestions of Krabbendam \& Wain (1997) that constrictional east-west extension, vertical thinning and north-south shortening occurred throughout the WGR during the late-Caledonian amphibolite-facies metamorphism. It is possible that other phases and/or rock types not measured in this study accommodated other strain geometries,

\section{Implications for interpreting quartz CPOs}

This study demonstrates that qualitative assessment of strain geometry is possible using quartz CPOs. There are three actions that would enable quantitative assessment of strain geometry.

1. Viscoplastic modeling of quartz CPOs (Wenk et al. 1989) must be expanded to include $\langle\mathrm{a}\rangle$ axes and conducted to sufficiently high strains to produce CPOs with strengths similar to natural CPOs.

2. A means of assessing the degree to which $\langle a\rangle$ axes deviate between maxima, girdles and random must be devised.

3. The initial work of Price (1985), comparing CPOs with measured strain geometries, must be expanded to complete crystal orientations using EBSD.

Although quartz CPOs with Type I and Type II (Lister 1977) $c$-axis girdles are common in the literature, and are indeed typical of some amphibolitefacies terranes (e.g. Lister \& Dornsiepen 1982; Schmid \& Casey 1986; Law 1990; Xypolias \& Koukouvelas 2001; Llana-Fúnez 2002), they are rare components of this dataset, implying a difference in deformation or that EBSD-generated CPOs look different or are different from U-stage generated CPOs.

\section{Conclusion}

Slip systems, sense of shear, CPO strength, and strain geometry across the ultrahigh-pressure Western Gneiss region of Norway were assessed using CPOs measured with EBSD. CPOs with $c$-axis maxima subparallel to $\mathrm{X}$ indicate local preservation of eclogite- or granulite-facies prism [c] slip. The bulk of the CPOs, however, have [c] axis maxima subparallel to $\mathrm{Y}$ or great-circle girdles subperpendicular to $\mathrm{X}$, implying a dominance of prism $\langle a\rangle$ slip and mixed $\langle a\rangle$ slip; this is the characteristic amphibolite-facies deformation of the Western Gneiss region. There are few Type I and Type II girdles, in contrast to other studies. Asymmetric and strong CPOs characterize the high-strain, top-W, normal-sense Nordfjord-Sogn Detachment Zone and a top-to-the-east domain along the eastern margin of the crystalline basement. The $c$-axis distributions of the CPOs suggest that the strain was characterized by a mix of plane strain and constriction and minimal flattening; this supports earlier field-based studies.

Funded by NSF EAR-0510453. Dedicated to M. Casey for his kindness and pioneering work on CPO measurement and interpretation. Extensive and thoughtful reviews by G. Lloyd and P. Xypolias, and discussions with P. Gans 
Table 1A. EBSD data

\begin{tabular}{|c|c|c|c|c|c|c|c|c|c|c|c|c|c|}
\hline & Rock & UTM & UTM & Foliation & ineation & $\mathrm{J}[\mathrm{c}]$ & $\mathrm{J}\langle\mathrm{a}\rangle$ & Dominant slip & $\mathrm{P}$ & $\mathrm{G}$ & $\mathrm{R}$ & Pn & Shear sense \\
\hline E9730H1 & gneiss & 501347 & 6885005 & $129 / 54$ & $167 / 41$ & 2.0 & 1.3 & $\operatorname{prism}\langle a\rangle$ & 0.23 & 0.41 & 0.36 & 0.36 & \\
\hline E9801i1 & quartzite & 475357 & 6904137 & $070 / 10$ & $105 / 01$ & 4.4 & 1.8 & $\operatorname{prism}\langle a\rangle$ & 0.60 & 0.20 & 0.20 & 0.75 & top $\mathrm{E}(?)$ \\
\hline E9801O1 & quartzite & 473503 & 6896805 & $177 / 59$ & $096 / 09$ & 2.7 & 1.5 & $\operatorname{prism}\langle a\rangle$ & 0.40 & 0.32 & 0.28 & 0.56 & dextral \\
\hline E9804H & gneiss & 418722 & 6913211 & $162 / 55$ & $241 / 05$ & 1.7 & 1.2 & $\langle$ a slip? & 0.18 & 0.41 & 0.41 & 0.30 & top W \\
\hline E9805B5 & vein & 421351 & 6897587 & $142 / 40$ & $061 / 30$ & 2.0 & 1.3 & $\operatorname{prism}\langle a\rangle$ & 0.82 & 0.14 & 0.04 & 0.85 & symmetrical \\
\hline E9805M & gneiss & 412438 & 6908815 & $138 / 35$ & $122 / 35$ & 2.7 & 1.4 & $\operatorname{prism}\langle a\rangle$ & 0.04 & 0.38 & 0.59 & 0.09 & symmetrical \\
\hline $\mathrm{E} 9805 \mathrm{~N}$ & gneiss & 412319 & 6908500 & $144 / 35$ & $078 / 15$ & 1.6 & 1.2 & prism + rhomb $\langle a\rangle$ & 0.21 & 0.20 & 0.58 & 0.52 & top E \\
\hline Е9809C6 & gneiss & 391713 & 6890278 & $082 / 25$ & $120 / 25$ & 1.2 & 1.1 & basal $\langle a\rangle$ & 0.08 & 0.12 & 0.79 & & top W \\
\hline E9810E & quartzite & 360714 & 6857805 & $302 / 07$ & $247 / 07$ & 4.0 & 1.7 & $\operatorname{prism}\langle a\rangle$ & 0.57 & 0.21 & 0.22 & 0.73 & symmetrical \\
\hline E9816B6 & gneiss & 412000 & 687890 & $045 / 40$ & $100 / 24$ & 2.4 & 1.4 & basal $\langle a\rangle$ & 0.33 & 0.29 & 0.38 & 0.54 & top W \\
\hline E9816E & gneiss & 431450 & 6875648 & $269 / 12$ & $114 / 11$ & 1.4 & 1.1 & $\langle a\rangle$ slip & 0.08 & 0.23 & 0.69 & & top W \\
\hline E9816F & gneiss & 433871 & 6875328 & $114 / 50$ & $054 / 25$ & 1.7 & 1.2 & basal $\langle a\rangle$ & 0.18 & 0.25 & 0.56 & 0.42 & sinistral \\
\hline E9818B & gneiss & 438451 & 6863002 & $028 / 45$ & $078 / 35$ & 1.8 & 1.2 & $\langle a\rangle$ slip & 0.11 & 0.39 & 0.50 & 0.22 & top W \\
\hline E9818F2 & gneiss & 428332 & 6875575 & 08046 & $112 / 40$ & 3.5 & 1.6 & $\operatorname{prism}\langle a\rangle$ & 0.47 & 0.23 & 0.30 & 0.67 & top $\mathrm{E}(?)$ \\
\hline E9819A & gneiss & 427527 & 6877800 & $050 / 43$ & $090 / 34$ & 4.3 & 1.7 & prism $\langle a\rangle$ & 0.54 & 0.23 & 0.23 & 0.70 & top W(?) \\
\hline E9820M9 & vein & 385400 & 686740 & $050 / 50$ & $075 / 19$ & 6.8 & 2.8 & prism $\langle a\rangle$ & 0.56 & 0.25 & 0.19 & 0.69 & \\
\hline E1606L5 & quartzite & 473777 & 6878900 & $147 / 85$ & $069 / 24$ & 2.4 & 1.5 & $\langle a\rangle$ slip & 0.21 & 0.58 & 0.21 & 0.27 & dextral \\
\hline E1606L6 & gneiss & 473777 & 6878900 & $090 / 70$ & $090 / 46$ & 2.0 & 1.3 & $\langle a\rangle$ slip & 0.13 & 0.55 & 0.33 & 0.19 & symmetrical \\
\hline E1608G1 & gneiss & 408854 & 6868422 & $005 / 74$ & $088 / 38$ & 3.7 & 1.9 & basal $\langle a\rangle$ & 0.15 & 0.39 & 0.45 & & \\
\hline E1612C9 & gneiss & 342678 & 6899395 & $137 / 10$ & $177 / 05$ & 1.9 & 1.2 & $\langle a\rangle$ slip & 0.16 & 0.27 & 0.58 & 0.37 & top $\mathrm{N}$ \\
\hline E1613P & gneiss & 410809 & 6901325 & $082 / 16$ & & 1.3 & 1.1 & $\langle a\rangle$ slip & 0.02 & 0.17 & 0.81 & & \\
\hline E1614A7 & granulite & 421807 & 6897223 & $045 / 36$ & $060 / 15$ & 10.1 & 2.8 & ? & 0.82 & 0.14 & 0.04 & & \\
\hline E1627E & gneiss & $514 \times x x$ & $6860 \times x x$ & $208 / 30$ & $276 / 13$ & 1.4 & 1.1 & $\langle a\rangle$ slip & 0.10 & 0.46 & 0.44 & 0.18 & symmetrical \\
\hline H1604I3 & gneiss & $5454 \times x$ & $70225 x x$ & $350 / 84$ & $078 / 24$ & 1.3 & 1.1 & $\langle$ a $\rangle$ slip & 0.07 & 0.32 & 0.61 & & dextral \\
\hline J2801C & quartzite & 336970 & 6842464 & $186 / 61$ & $277 / 15$ & 1.5 & 1.1 & $\langle a\rangle$ slip & 0.06 & 0.49 & 0.45 & 0.11 & sinistral \\
\hline $\mathrm{J} 2802 \mathrm{H} 1$ & quartzite & 335811 & 6848823 & $349 / 29$ & $265 / 05$ & 4.1 & 1.7 & $\operatorname{prism}\langle a\rangle$ & 0.60 & 0.21 & 0.20 & 0.74 & top W \\
\hline $\mathrm{J} 2802 \mathrm{~L}$ & quartzite & 333726 & 6848065 & $186 / 80$ & $270 / 10$ & 4.2 & 1.7 & prism $\langle a\rangle$ & 0.59 & 0.26 & 0.15 & 0.70 & sinistral \\
\hline $\mathrm{J} 2802 \mathrm{~S} 2$ & quartzite & 331352 & 6845675 & $210 / 40$ & $215 / 38$ & 1.7 & 1.2 & $\langle a\rangle$ slip & 0.09 & 0.57 & 0.34 & 0.14 & top W \\
\hline J2803M & quartzite & 325790 & 6036350 & $347 / 26$ & $286 / 12$ & 2.2 & 1.3 & basal $\langle a\rangle$ & 0.18 & 0.59 & 0.23 & 0.23 & top W \\
\hline J2804L2 & gneiss & 323903 & 6830723 & $198 / 26$ & $287 / 02$ & 2.2 & 1.3 & $\operatorname{prism}\langle a\rangle$ & 0.39 & 0.26 & 0.35 & 0.60 & top $\mathrm{E}$ \\
\hline J2804L31 & quartzite & 323903 & 6830723 & $198 / 26$ & $287 / 02$ & 6.6 & 2.2 & prism $\langle a\rangle$ & 0.77 & 0.13 & 0.10 & 0.86 & top $\mathrm{W}(?)$ \\
\hline $\mathrm{J} 2805 \mathrm{~S}$ & quartzite & 294817 & 6836146 & $015 / 69$ & $092 / 28$ & 2.6 & 1.3 & prism $\langle a\rangle$ & 0.30 & 0.45 & 0.25 & 0.40 & sinistral \\
\hline $\mathrm{J} 2806 \mathrm{~A} 2$ & quartzite & 318548 & 6842979 & $304 / 25$ & $291 / 20$ & 2.3 & 1.3 & prism $\langle a\rangle$ & 0.37 & 0.35 & 0.29 & 0.51 & top $\mathrm{W}$ \\
\hline $\mathrm{J} 2812 \mathrm{~A}$ & quartzite & 312165 & 6835751 & $347 / 34$ & $299 / 22$ & 1.9 & 1.2 & prism $\langle a\rangle$ & 0.15 & 0.56 & 0.29 & 0.22 & top W \\
\hline $\mathrm{J} 2813 \mathrm{D}$ & quartzite & 330516 & 6841848 & $201 / 73$ & $282 / 28$ & 2.3 & 1.3 & basal $\langle a\rangle$ & 0.36 & 0.33 & 0.31 & 0.52 & sinistral \\
\hline J2818J & quartzite & 341050 & 6837880 & $342 / 30$ & $284 / 19$ & 2.0 & 1.3 & $\langle$ a $\rangle$ slip & 0.18 & 0.51 & 0.31 & 0.26 & top E \\
\hline
\end{tabular}


J2819D

J3628B

J3630D

J3701E3

J3701E4

$\mathrm{J} 3705 \mathrm{H}$

J5814C

J5814N2

J5815C

J5815E4

J5815F2

J5816L2

K7708J

K7709H6

K7710R1

K7710R2

K7710S

K7711D

K7711E1

K7711E2

K7711E3

K7711K

K7714A2

K7716A

K7717A

K7717G

K7719A

K7721C

P6803A2

P6807F7

P6807F8

P6807F9

P6807G2

P6808A3

P6809A3

P6821D1

P6822B1

$\mathrm{P} 6824 \mathrm{C} 1$

P6824C2

$\mathrm{P} 6824 \mathrm{C} 2$

P6826E1

$8815 \mathrm{G} 11$ quartzite

quartzite

332184

quartzite

Ultramylon

Ultramylon

quartzite

gneiss

gneiss

gneiss

gneiss

vein

quartzite

vein

quartzite

vein

quartzite

gneiss

gneiss

gneiss

vein

quartzite

gneiss

gneiss

gneiss

vein in eclc

granulite

quartzite

quartzite

gneiss

vein in eclc

vein

eclogite

eclogite

gneiss

gneiss

gneiss

gneiss

gneiss

gneiss

vein

gneiss

gneiss 322608

325260

325260

342090

465986

454500

392259

398970

394992

506601

527070

506173

488814

488814

488584

495410

495414

495414

495414

499xxx

329382

310706

313814

292229

427817

481595

440197

301660

301660

301660

302307

491800

463565

345700

334890

294809

292xxx

292xxx

383482

319906

\section{$275 / 30$}

$308 / 09 \quad 277 / 08$

$313 / 09 \quad 292 / 08$

$252 / 28 \quad 294 / 22$

$004 / 70 \quad 271 / 10$

$070 / 40 \quad 070 / 40$

$335 / 85 \quad 065 / 06$

$185 / 84 \quad 270 / 35$

$168 / 80 \quad 082 / 01$

$160 / 10 \quad 067 / 01$

$267 / 73 \quad 210 / 62$

$099 / 29 \quad 125 / 26$

$344 / 24 \quad 030 / 05$

$145 / 05 \quad 105 / 05$

$145 / 05 \quad 105 / 05$

095/05 102/05

$080 / 10 \quad 080 / 10$

$155 / 15 \quad 096 / 12$

$132 / 15 \quad 096 / 12$

$155 / 15 \quad 096 / 12$

$350 / 67 \quad 08001$

$132 / 78 \quad 051 / 36$

$120 / 24 \quad 110 / 19$

$145 / 60 \quad 230 / 15$

065/89 320/05

$008 / 42 \quad 292 / 06$

$330 / 30 \quad 245 / 05$

$170 / 49 \quad 125 / 35$

$020 / 55 \quad 108 / 20$

$035 / 50 \quad 110 / 15$

$120 / 20 \quad 132 / 15$

$060 / 31 \quad 115 / 10$

$025 / 35$

$080 / 20$

$094 / 39$

$100 / 18$

6851400

$047 / 50$

6878942

6883xxx

6883xxx

6929460

6907793
$075 / 20$

$117 / 75$

$010 / 42$

$006 / 35$

$006 / 35$

$280 / 05$

$280 / 05$

$220 / 50$

$130 / 01$
$071 / 11 \quad 089 / 11$ prism $\langle a\rangle$

prism $\langle a\rangle$

prism $\langle a\rangle$

prism $\langle a\rangle$

$\langle$ a slip

prism $\langle a\rangle$

prism $\langle\mathrm{a}\rangle$

$\langle$ a $\rangle$ slip

prism $\langle a\rangle$

basal-prism $\langle a\rangle$

prism $\langle a\rangle$

basal $\langle a\rangle$ ?

〈a slip

prism $\langle a\rangle$ ?

prism $\langle a\rangle$

prism $\langle a\rangle$

prism $\langle a\rangle$

prism $\langle a\rangle$

prism $\langle a\rangle$

prism $\langle a\rangle$ ?

(a) slip

$\langle$ a slip

prism $\langle a\rangle$

$\langle$ a slip

prism [c]

basal+rhomb $\langle a\rangle$

prism $\langle\mathrm{a}\rangle$ ?

prism $\langle a\rangle$

basal $\langle a\rangle$ ?

prism [c]?

〈a) slip

prism [c]

prism [c]?

prism $\langle\mathrm{a}\rangle$

prism $\langle a\rangle$

$\langle$ a slip

basal $\langle a\rangle$

prism $\langle a\rangle$ ?

prism $\langle a\rangle$

prism $\langle a\rangle$

basal $\langle a\rangle$ ?

$\operatorname{prism}\langle a\rangle$

0.23

.39

20

0.20
0.32

0.32

0.51

0.10

0.13

0.12

0.53

0.44

0.04

0.39

0.73

0.59

0.57

0.23

0.17

0.44

0.18

0.11

0.25

0.22

0.54

0.21

0.50

0.76

0.12

0.10

0.33

0.29

0.14

0.21

0.48

0.12

0.43

0.23

0.12

0.48

0.38

0.42

2.6

- -

1.4

0.24

0.30

top $\mathrm{E}$

0.33

0.65

0.30

0.23

0.34

0.03

0.37

0.29

0.18

0.42 
Table 1A. Continued

\begin{tabular}{|c|c|c|c|c|c|c|c|c|c|c|c|c|c|}
\hline & Rock & UTM & UTM & Foliation & ineation & $\mathrm{J}[\mathrm{c}]$ & $\mathrm{J}\langle\mathrm{a}\rangle$ & Dominant slip & $\mathrm{P}$ & $\mathrm{G}$ & $\mathrm{R}$ & Pn & Shear sense \\
\hline 8829A2 & gneiss & 302350 & 6924950 & None & & 1.2 & 1.0 & basal $\langle a\rangle$ ? & 0.06 & 0.16 & 0.78 & & \\
\hline 8830B9 & vein & 328000 & 6920100 & $178 / 89$ & $091 / 02$ & 2.3 & 1.6 & $\langle a\rangle$ slip & 0.16 & 0.18 & 0.66 & & sinistral(?) \\
\hline R8906B9 & vein & 325000 & 6921700 & $142 / 35$ & $271 / 09$ & 3.9 & 1.9 & $\operatorname{prism}\langle a\rangle$ & 0.39 & 0.20 & 0.41 & 0.67 & top E \\
\hline R9823F9 & gneiss & 336147 & 6911512 & $157 / 70$ & $115 / 70$ & 2.2 & 1.3 & $\langle a\rangle$ slip & 0.35 & 0.14 & 0.52 & 0.72 & \\
\hline R9823I9 & gneiss & 325833 & 6923822 & $130 / 70$ & $210 / 75$ & 1.7 & 1.2 & prism $[\mathrm{c}]$ & 0.25 & 0.23 & 0.52 & 0.52 & top $\mathrm{E}$ \\
\hline R9824B7 & eclogite bo & 327304 & 6923241 & $140 / 26$ & $100 / 30$ & 1.6 & 1.2 & prism $[\mathrm{c}]$ ? & 0.03 & 0.46 & 0.50 & 0.06 & \\
\hline R9826C & gneiss & 329191 & 6914284 & $146 / 21$ & $108 / 29$ & 1.8 & 1.3 & basal $\langle a\rangle$ & 0.09 & 0.20 & 0.71 & & symmetrical \\
\hline R9828C98 & quartzite & 313872 & 6908472 & $027 / 55$ & $090 / 09$ & 4.0 & 1.8 & prism $\langle a\rangle ?$ & 0.33 & 0.35 & 0.31 & 0.49 & \\
\hline Y0814I & Ultramylon & 361485 & 6845158 & $350 / 24$ & $085 / 11$ & 8.6 & 3.1 & prism $\langle a\rangle$ & 0.73 & 0.22 & 0.05 & 0.77 & top W \\
\hline Y0815M & quartzite & 360353 & 6849154 & $023 / 31$ & $102 / 05$ & 5.1 & 2.1 & prism $\langle a\rangle$ & 0.58 & 0.34 & 0.08 & 0.63 & top W \\
\hline Y0821D & quartzite & 367921 & 6849700 & $275 / 30$ & $267 / 25$ & 3.0 & 1.5 & prism $\langle a\rangle$ & 0.45 & 0.28 & 0.27 & 0.61 & symmetrical \\
\hline YQ822D & vein & 371394 & 6857253 & $313 / 15$ & $271 / 13$ & 8.3 & 2.9 & prism $\langle a\rangle$ & 0.74 & 0.23 & 0.03 & 0.76 & top $\mathrm{W}$ \\
\hline Y0822J & quartzite & 366990 & 6854913 & $254 / 22$ & $283 / 10$ & 4.9 & 1.9 & prism $\langle a\rangle$ & 0.63 & 0.23 & 0.14 & 0.73 & top W \\
\hline Y0824P & quartzite & 367499 & 6858991 & $306 / 12$ & $262 / 09$ & 7.0 & 2.3 & prism $\langle a\rangle$ & 0.67 & 0.27 & 0.06 & 0.71 & top E \\
\hline Y0829J & quartzite & 348041 & 6857702 & $160 / 25$ & $092 / 04$ & 3.0 & 1.6 & $\langle a\rangle$ slip & 0.32 & 0.51 & 0.17 & 0.39 & top W \\
\hline Y1518C & vein & 352765 & 6851478 & $030 / 41$ & $094 / 15$ & 3.4 & 1.7 & $\operatorname{prism}\langle a\rangle$ & 0.29 & 0.57 & 0.13 & 0.34 & top W \\
\hline Y1524K & vein & 375864 & 6864388 & $218 / 50$ & $271 / 25$ & 5.6 & 2.1 & prism $\langle a\rangle$ & 0.51 & 0.44 & 0.05 & 0.53 & top W \\
\hline Y1526E & anorthosite & 369700 & 6869200 & $048 / 52$ & $050 / 45$ & 1.6 & 1.1 & $\langle a\rangle$ slip & 0.19 & 0.24 & 0.57 & 0.44 & top W \\
\hline Y1530D & quartzite & 369620 & 6860160 & $205 / 28$ & $268 / 13$ & 3.6 & 1.7 & $\operatorname{prism}\langle a\rangle$ & 0.49 & 0.36 & 0.15 & 0.58 & top W \\
\hline Y1612D & vein & 352725 & 6868464 & $172 / 89$ & $256 / 08$ & 7.1 & 2.2 & prism [c] & 0.50 & 0.33 & 0.17 & 0.60 & sinistral \\
\hline Y1617B5 & gneiss & 325853 & 6868800 & None & & 1.3 & 1.1 & prism [c]? & 0.13 & 0.21 & 0.66 & & \\
\hline Y1618E4 & anorthosite & 314162 & 6871113 & $345 / 63$ & $065 / 40$ & 1.6 & 1.2 & $\langle a\rangle$ slip & 0.13 & 0.19 & 0.68 & & \\
\hline Y1706B & vein\&gneis & 326564 & 6865755 & $316 / 80$ & $225 / 06$ & 2.4 & 1.3 & prism $[\mathrm{c}]$ & 0.30 & 0.22 & 0.49 & 0.58 & sinistral \\
\hline
\end{tabular}

Foliation and lineation are given as dip and dip direction; azimuth and plunge. $\mathrm{J}[\mathrm{c}]$ and $\mathrm{J}\langle\mathrm{a}\rangle$ indicate strength of $[\mathrm{c}]$ and $\langle\mathrm{a}\rangle$ axis CPOs.

$\mathrm{P}, \mathrm{G}$, and $\mathrm{R}$ indicate extent to which [c] axis CPO forms a point, girdle, or random distribution.

$\mathrm{Pn}=\mathrm{P} /(\mathrm{P}+\mathrm{G})$. Not calculated for samples with high $\mathrm{R}$ values or obscure CPOs.

fsp $\%$ includes plagioclase and K-feldspar; chl, chlorite; ep, epidote/zoisite; gar, garnet; hbl, hornblende; kspar, K-feldspar. 
Table 2A. Additional sample attributes

\begin{tabular}{|c|c|c|c|c|c|c|c|c|}
\hline & Quartz (\%) & fsp $\%$ & Other $(\%)$ & Other minerals & Quartz regime & $\begin{array}{l}\text { Quartz undulose } \\
\text { extinction }\end{array}$ & $\begin{array}{c}\text { Subgrain } \\
\text { development }\end{array}$ & $\begin{array}{l}\text { Grain-boundary } \\
\text { tortuosity }\end{array}$ \\
\hline E9730H1 & 30 & 60 & 10 & gar, mica, hbl & 3 & strong & moderate & strong \\
\hline E9801i1 & 85 & 10 & 5 & mica & 2 & strong & strong & very strong \\
\hline E980101 & 75 & 15 & 10 & mica & 3 & strong & moderate & moderate \\
\hline E9804H & 60 & 35 & 5 & mica & 3 & moderate to weak & moderate & weak to moderate \\
\hline E9805B5 & 100 & 0 & 0 & & & ultramylonite & ultramylonite & ultramylonite \\
\hline E9805M & 50 & 40 & 10 & mica & 3 & moderate & moderate to strong & moderate \\
\hline E9805N & 85 & 10 & 5 & mica & 3 & moderate & moderate & weak to moderate \\
\hline E9809C6 & 20 & 55 & 15 & mica & 3 & moderate & moderate & moderate \\
\hline E9810E & 80 & 15 & 5 & kspar, mica & 3 & moderate & weak & moderate \\
\hline E9816B6 & 30 & 70 & 0 & & 3 & strong & strong & strong \\
\hline E9816E & 85 & 10 & 5 & mica & 3 & moderate & weak to moderate & moderate \\
\hline E9816F & 40 & 30 & 30 & gar, mica & 3 & weak & weak & straight to weak \\
\hline E9818B & 80 & 15 & 5 & mica & 3 & strong & strong & strong \\
\hline E9818F2 & 85 & 10 & 5 & kspar, mica & 2 & strong & strong & strong \\
\hline E9819A & 75 & 25 & 0 & kspar, mica & 2 to 3 & strong to moderate & strong to moderate & strong \\
\hline E9820M9 & 100 & 0 & 0 & & 3 & strong & strong & strong \\
\hline E1606L5 & 100 & 0 & 0 & & 3 & moderate & moderate & moderate to strong \\
\hline E1606L6 & 55 & 35 & 10 & mica, ep & 3 & moderate & moderate & straight \\
\hline E1608G1 & 30 & 55 & 15 & mica & 3 & strong & moderate & strong \\
\hline E1612C9 & 20 & 75 & 5 & mica & 3 & weak & weak & straight \\
\hline E1613P & 40 & 50 & 10 & mica, kspar & 3 & very strong & strong & strong \\
\hline E1614A7 & 25 & 70 & 5 & & & weak & weak & straight \\
\hline E1627E & 45 & 50 & 5 & mica & 3 & strong & moderate & pinned by feldspars \\
\hline $\mathrm{H} 1604 \mathrm{I} 3$ & 25 & 70 & 5 & mica, ep, sph & 3 & moderate & moderate & weak \\
\hline J2801C & 60 & 40 & 0 & kspar & 2 to 3 & strong & strong & strong \\
\hline $\mathrm{J} 2802 \mathrm{H} 1$ & 65 & 25 & 10 & kspar, mica & 2 & strong & moderate & very strong \\
\hline $\mathrm{J} 2802 \mathrm{~L}$ & 65 & 35 & 0 & kspar & 2 & strong & moderate & very strong \\
\hline $\mathrm{J} 2802 \mathrm{~S} 2$ & 50 & 50 & 0 & & 3 & strong & moderate & strong \\
\hline $\mathrm{J} 2803 \mathrm{M}$ & 60 & 30 & 10 & kspar, mica & 2 & strong & strong & strong \\
\hline J2804L2 & 55 & 10 & 35 & mica, kspar & 2 to 3 & strong & strong & strong \\
\hline J2804L31 & 70 & 25 & 5 & kspar, mica & 2 & strong & strong & moderate to strong \\
\hline $\mathrm{J} 2805 \mathrm{~S}$ & 70 & 25 & 5 & kspar, mica & 2 to 3 & strong & strong & strong \\
\hline $\mathrm{J} 2806 \mathrm{~A} 2$ & 70 & 25 & 5 & kspar, mica & 2 & strong & strong & strong \\
\hline $\mathrm{J} 2812 \mathrm{~A}$ & 75 & 20 & 0 & mica & 2 & strong & strong & strong \\
\hline $\mathrm{J} 2813 \mathrm{D}$ & 85 & 10 & 5 & kspar, mica & 2 & strong & strong & strong \\
\hline
\end{tabular}




\section{Table 2A. Continued}

Quartz (\%) fsp $\% \quad$ Other $(\%) \quad$ Other minerals $\quad$ Quartz regime

Quartz undulose

extinction

Subgrain

development

strong

strong

moderate

kspar, mica, sph

mica

kspar, mica

mica, chl

gar, mica, ky, mica

gar, mica

gar, mica

gar, mica

kspar, mica

mica

mica

mica

kspar, mica

mica

mica

mica, ep

kspar

mica, sph

mica

mica, sph

hbl, ep

gar, ep, mica, chl

hbl, gar, ru

gar, sph

mica

mica

mica, gar

gar, mica, chl strong

moderate

moderate

ultramylonite

ultramylonite

strong

moderate

moderate

strong

moderate

moderate

weak

moderate

low to moderate

strong

strong

strong

moderate

strong

strong

strong

moderate

moderate

moderate

weak

weak

strong

strong

very strong

weak

strong

weak

weak

moderale

moderate moderate moderate

ultramylonite

ultramylonite

moderate

pinned

moderate

strong

moderate

moderate

moderate

moderate

weak

moderate

moderate

strong

moderate

strong

strong

strong

moderate

moderate

moderate

weak

weak to moderate

strong

moderate

strong

weak

strong

weak

moderate

moderate

moderate

weak
Grain-boundary tortuosity strong

moderate

moderate

moderate

ultramylonite

ultramylonite

strong

pinned

moderate

strong

weak to moderate

moderate

strong

moderate

moderate to straight

moderate to strong

moderate to strong

strong

moderate to strong

strongly strong

strongly strong

strongly strong

moderate

straight

weak to moderate

straight

straight to weak

strong

relatively strong

strongly strong

straight

moderate

straight to weak

straight

modest

moderate

relatively strong 
gar, hbl, cpx, mica

$8815 \mathrm{G} 11$

8829A2

$8830 \mathrm{~B} 9$

R8906B9

R9823F9

R9823I9

R9824B7

R9826C

R9828C98

Y0814I

Y0815M

Y0821D

Y0822D

Y0822J

Y0824P

Y0829J

Y1518C

Y1524K

Y1526E

Y1530D

Y1612D

Y1617B5

Y1618E4

Y1706B kspar

mica, opx, gar, ky

kspar, mica

kspar, mica

gar, hbl, mica, chl

mica, sph

gar, amph

mica

mica

kspar, mica

mica

mica, sph

kspar, ep, hbl

2 to 3

3
3 weak

moderate

weak

moderate

2 to 3 moderate

isolated qtz grains

weak

strong

weak

weak

moderate to strong

strong

strong

moderate

strong

weak

strong

strong

moderate

strong

strong

moderate to strong

strong

weak

strong

strong

moderate

isolated qtz grains

weak

strong

weak

moderate to weak

moderate to strong

strong

strong

moderate

strong

moderate

strong

moderate

moderate

strong

strong

moderate

moderate to strong

weak

moderate to strong

strong

moderate

isolated qtz grains strong moderate

isolated qtz grains strong straight

3 raight

straight

straight to weak

moderate to strong

isolated qtz grains

straight

very strong

weak to moderate

straight to weak

straight to weak

strong

moderate

weak to moderate

strong

straight

strong

strong

moderate

very strong

strong

moderate

strong

straight

strong

strong

weak to moderate

isolated qtz grains strong

fsp\% includes plagioclase and K-feldspar; chl, chlorite; ep, epidote/zoisite; gar, garnet; hbl, hornblende; kspar, K-feldspar; ky, kyanite; opx, orthopyroxene; ru, rutile; zo, zoisite. 


\section{References}

ABAlos, B. 1997. Omphacite fabric variation in the Cabo Ortegal Eclogite (NW Spain); relationships with strain symmetry during high-pressure deformation. Journal of Structural Geology, 19, 621-637.

Andersen, T. B. \& JAmTVEIT, B. 1990. Uplift of deep crust during orogenic extensional collapse: a model based on field studies in the Sogn-Sunnfjord region of western Norway. Tectonics, 9, 1097-1111.

Andersen, T. B., Osmundsen, P. T. \& Jolivet, L. 1994. Deep crustal fabrics and a model for the extensional collapse of the southwest Norwegian Caledonides. Journal of Structural Geology, 16, $1191-1203$.

Andersen, T. B., Jamtveit, B., Dewey, J. F. \& SWENSSON, E. 1991. Subduction and exhumation of continental crust: major mechanism during continentcontinent collision and orogenic extensional collapse, a model based on the south Caledonides. Terra Nova, 3, 303-310.

BAËTA, R. D. \& AshbeE, K. H. G. 1969. Slip systems in quartz: I. Experiments, American Mineralogist, 54, $1551-1573$.

Bascou, J., Tommasi, A. \& Mainprice, D. 2002. Plastic deformation and development of clinopyroxene lattice preferred orientations in eclogites. Journal of Structural Geology, 24, 1357-1368.

Behrmann, J. H. \& Platt, J. P. 1982. Sense of nappe emplacement from quartz c-axis fabrics: an example from the Betic Cordilleras (Spain). Earth and Planetary Science Letters, 59, 208-215.

BLACIC, J. D. 1975. Plastic-deformation mechanisms in quartz; the effect of water. Tectonophysics, 27, $271-294$

Blacic, J. D. \& Christie, J. M. 1984. Plasticity and hydrolytic weakening of quartz single crystals. Journal of Geophysical Research, 89, 4223-4239.

Blumenfeld, P., Mainprice, D. \& Bouchez, J.-L. 1986. C-slip in quartz from subsolidus deformed granite. Tectonophysics, 127, 97-115.

BouCHEZ, J.-L. 1977. Plastic deformation of quartzites at low temperature in an area of natural strain gradient. Tectonophysics, 39, 25-50.

Bouchez, J.-L., Lister, G. S. \& Nicolas, A. 1983. Fabric asymmetry and shear sense in movement zones, Geologische Rundschau, 72, 410-419.

Bunge, H.-J. 1977. Texture Analysis in Materials Science. Butterworths, London.

Carreras, J., Estrada, A. \& White, S. 1977. The effects of folding on the c-axis fabrics of a quartz mylonite. Tectonophysics, 39, 3-24.

Casey, M. \& MCGrew, A. J. 1999. One-dimensional kinematic model of preferred orientation development. Tectonophysics, 303, 131-140.

Christie, J. M., Griggs, D. T. \& Carter, N. L. 1964. Experimental evidence of basal slip in quartz. Journal of Geology, 72, 734-756.

Dell'Angelo, L. N. \& Tullis, J. 1989. Fabric development in experimentally sheared quartzites. Tectonophysics, 169, 1-22.

Griffin, W. L., Austrheim, H. et al. 1985. Highpressure metamorphism in the Scandinavian Caledonides. In: GeE, D. G. \& Sturt, B. A. (eds) The
Caledonide Orogen; Scandinavia and related areas. John Wiley \& Sons, Chichester, 783-801.

HACKER, B. R. 2007. Ascent of the ultrahigh-pressure Western Gneiss Region, Norway. In: Cloos, M., Carlson, W. D., Gilbert, M. C., Liou, J. G. \& Sorenson, S. S. (eds) Convergent Margin Terranes and Associated Regions: A Tribute to W.G. Ernst. Geological Society of America Special Paper, 419, $171-184$.

Hacker, B. R. \& PeAcock, S. M. 1995. Creation, preservation, and exhumation of coesite-bearing, ultrahighpressure metamorphic rocks. In: COLEMAN, R. G. \& Wang, X. (eds) Ultrahigh Pressure Metamorphism. Cambridge University Press, Cambridge, 159-181.

Hacker, B. R., Andersen, T. B., Root, D. B., Mehl, L., Mattinson, J. M. \& Wooden, J. L. 2003. Exhumation of high-pressure rocks beneath the Solund Basin, Western Gneiss Region of Norway. Journal of Metamorphic Geology, 21, 613-629.

Heilbronner, R. \& Tullis, J. 2006. Evolution of $c$-axis pole figures and grain size during dynamic recrystallization: results from experimentally sheared quartzite. Journal of Geophysical Research, 111, B10202, doi: 10.1029/2005JB004194.

HIRTH, G. \& TULlis, J. 1992. Dislocation creep regimes in quartz aggregates. Journal of Structural Geology, 14, 145-159.

Johnston, S., Hacker, B. R. \& Andersen, T. B. 2007a. Exhuming Norwegian ultrahigh-pressure rocks: Overprinting extensional structures and the role of the Nordfjord-Sogn Detachment Zone. Tectonics, 26, TC5001, doi: 10.1029/2005TC001933.

Johnston, S., Hacker, B. R. \& DuCEA, M. N. $2007 b$. Exhumation of ultrahigh-pressure rocks beneath the Hornelen segment of the Nordfjord-Sogn Detachment Zone, western Norway. Geological Society of America Bulletin, 119, 1232-1248.

KNIPE, R. J. \& LAw, R. D. 1987. The influence of crystallographic orientation and grain-boundary migration on microstructural and textural evolution in an SC mylonite. Tectonophysics, 135, 153-169.

Krabbendam, M. \& Wain, A. 1997. Late-Caledonian structures, differential retrogression and structural position of (ultra) high pressure rocks in the NordfjordStadlandet area, Western Gneiss Region. Norges Geologiske Undersøkelse Bulletin, 432, 127-139.

KYLANDER-ClARK, A. R. C., HACKER, B. R., JOHNSON, C. M., BeArd, B. L., Mahlen, N. J. \& LApen, T. J. 2007. Timing of multi-stage metamorphism during ultrahigh-pressure continental subduction and exhumation: $\mathrm{Lu} / \mathrm{Hf}$ and $\mathrm{Sm} / \mathrm{Nd}$ geochronology in western Norway. Chemical Geology, 232, 137-154.

Kylander-Clark, A. R. C., Hacker, B. R. \& Mattinson, J. M. 2008. Slow exhumation of UHP terranes: titanite and rutile ages of the Western Gneiss Region, Norway. Earth and Planetary Science Letters, 272, 531-540.

Labrousse, L., Jolivet, L., Agard, P., Hébert, R. \& Andersen, T. B. 2002. Crustal-scale boudinage and migmatization of gneiss during their exhumation in the UHP Province of Western Norway. Terra Nova, 14, 263-270.

LAW, R. D. 1986. Relationships between strain and quartz crystallographic fabrics in the Roche Maurice 
quartzites of Plougastel, western Brittany. Journal of Structural Geology, 8, 493-515.

LAW, R. D. 1990. Crystallographic fabrics: a selective review of their application to research in structural geology. In: KNIPE, R. J. \& RutTeR, E. H. (eds) Deformation Mechanisms, Rheology and Tectonics. Geological Society, London, Special Publications, 54, 335-352.

LENZE, A. \& STÖCKHERT, B. 2007. Microfabrics of UHP metamorphic granites in the Dora Maira Massif, western Alps - no evidence of deformation at great depth. Journal of Metamorphic Geology, 25, 461-475.

Linker, M. F., Kirby, S. H., ORD, A. \& Christie, J. M. 1984. Effects of compression direction on plasticity and rheology of hydrolytically weakened synthetic quartz at atmospheric pressure. Journal of Geophysical Research, 89, 4241-4255.

Lister, G. S. 1977. Discussion; crossed-girdle c-axis fabrics in quartzites plastically deformed by plane strain and progressive simple shear. Tectonophysics, 39, $51-54$.

LISTER, G. S. 1982. A vorticity equation for lattice reorientation during plastic deformation. Tectonophysics, 82, 351-366.

Lister, G. S. \& Dornsiepen, U. F. 1982. Fabric transitions in the Saxony granulite terrain. Journal of Structural Geology, 11, 65-94.

Lister, G. S. \& HobBs, B. E. 1980. The simulation of fabric development during plastic deformation and its application to quartzite: the influence of deformation history. Journal of Structural Geology, 2, 355-370.

Lister, G. S., Paterson, M. \& HobBs, B. E. 1978. The simulation of fabric development during plastic deformation and its application to quartzite: the model. Tectonophysics, 45, 107-158.

LLANA-FÚNEZ, S. 2002. Quartz c-axis texture mapping of a Variscan regional foliation (Malpica-Tui Unit, NW Spain). Journal of Structural Geology, 24, 1299-1312.

Lloyd, G. E. 2004. Microstructural evolution in a mylonitic quartz simple shear zone; the significant roles of Dauphiné twinning and misorientation. In: Alsop, G. I., Holdsworth, R. E., McCaffrey, K. \& Hand, M. (eds) Transports and Flow Processes in Shear Zones. Geological Society, London, Special Publications, 224, 39-224.

MAINPRICE, D. 2005. Pfch5 [Computer software], edited by ftp://www.gm.univ-montp2.fr/mainprice//CareWare_Unicef_Programs/.

MARJORIBANKS, R. W. 1976. The relation between microfabric and strain in a progressively deformed quartzite sequence from central Australia. Tectonophysics, 32, 269-293.

Miller, D. M. \& Christie, J. M. 1981. Comparison of quartz microfabric with strain in recrystallized quartzite. Journal of Structural Geology, 3, 129-141.

PRICE, G. P. 1985. Preferred orientations in quartzites. In: Wenk, H. R. (ed.) Preferred Orientation in Deformed Metals and Rocks: An Introduction to Modern Texture Analysis. Academic Press, Inc., Orlando, 385-406.

SCHMID, S. M. \& CASEY, M. 1986. Complete fabric analysis of some commonly observed quartz c-axis patterns. In: HoBBS, B. E. \& HEARD, H. C. (eds)
Mineral and Rock Deformation Laboratory Studies: The Paterson Volume. American Geophysical Union, Geophysical Monograph, 36, 263-286.

Stipp, M., Stünitz, H., HeIlbronner, R. \& SChmid, S. 2002. Dynamic recrystallization of quartz: correlation between natural and experimental conditions. In: De Meer, S., Drury, M. R., De Bresser, J. H. P. \& PenNock, G. M. (eds) Deformation Mechanisms, Rheology and Tectonics: Current Status and Future Perspectives. Geological Society, London, Special Publications, 200, 171-190.

TAYLOR, G. I. 1938. Plastic strain in metals. Journal Institute of Metals, 62, 307-324.

TERry, M. P. \& Robinson, P. 2003. Evolution of amphibolite-facies structural features and boundary conditions for deformation during exhumation of high- and ultrahigh-pressure rocks, Nordøyane, Western Gneiss Region, Norway. Tectonics, 22, 1036, doi: 10.1029/2001TC001349.

TERry, M. P. \& Robinson, P. 2004. Geometry of eclogite-facies structural features: implications for production and exhumation of UHP and HP rocks, Western Gneiss Region, Norway. Tectonics, 23, doi: 10.1029/2002TC001401.

Tullis, J., Christie, J. M. \& Griggs, D. T. 1973. Microstructure and preferred orientations of experimentally deformed quartzites. Geological Society of America Bulletin, 84, 297-314.

ULRICH, S. \& MAINPRICE, D. 2005. Does cation ordering in omphacite influence development of latticepreferred orientation? Journal of Structural Geology, 27, 419-431.

VOLLMER, F. W. 1990. An application of eigenvalue methods to structural domain analysis. Geological Society of America Bulletin, 102, 786-791.

Walsh, E. O. \& HACKeR, B. R. 2004. The fate of subducted continental margins: two-stage exhumation of the high-pressure to ultrahigh-pressure Western Gneiss complex, Norway. Journal of Metamorphic Geology, 22, 671-689.

Walsh, E. O., Hacker, B. R., Grove, M., Gans, P. B. $\&$ Gehrels, G. 2007. Timing the exhumation of (ultra)high-pressure rocks across the Western Gneiss Region, Norway. Geological Society of America Bulletin, 119, 289-301.

Wenk, H. R. \& Christie, J. M. 1991. Comments on the interpretation of deformation textures in rocks. Journal of Structural Geology, 13, 1091-1110.

Wenk, H.-R., Canova, G., Molinari, A. \& Kocks, U. F. 1989. Viscoplastic modeling of texture development in quartzite. Journal of Geophysical Research, 94, 17895-17906.

Woodcock, N. H. 1977. Specification of fabric shapes using an eigenvalue method. Geological Society of America Bulletin, 88, 1231-1236.

Xypolias, P. \& Koukouvelas, I. K. 2001. Kinematic vorticity and strain rate patterns associated with ductile extrusion in the Chelmos shear zone (external Hellenides, Greece). Tectonophysics, 338, 59-77.

Young, D. 2005. Amphibolite to Ultrahigh-Pressure Transition in Western Norway. Unpublished PhD thesis, University of California, Santa Barbara. 